\title{
Monitoring summer indoor overheating in the London housing stock
}

\author{
A. Pathan ${ }^{a}$, A. Mavrogiannia,*, A. Summerfield ${ }^{b}$, T. Oreszczyn ${ }^{b}$ and M. Davies ${ }^{a}$
}

${ }^{a}$ UCL Institute for Environmental Design and Engineering (IEDE), The Bartlett School of Environment, Energy and Resources (BSEER), The Bartlett Faculty of the Built Environment, University College London (UCL), Central House, 14 Upper Woburn Place, London WC1H ONN, UK

${ }^{b}$ UCL Energy Institute, The Bartlett School of Environment, Energy and Resources (BSEER), The Bartlett Faculty of the Built Environment, University College London (UCL), Central House, Central House, 14 Upper Woburn Place, London WC1H ONN, UK

* Corresponding author: Tel: +44 (0) 203108 5903; E-mail address: a.mavrogianni@ucl.ac.uk

\begin{abstract}
A B S T R A C T
In light of current climate change projections in recent years, there has been an increasing interest in the assessment of indoor overheating in domestic environments in previously heating-dominated climates. This paper presents a monitoring study of overheating in 122 London dwellings during the summers of 2009 and 2010. Dry Bulb Temperature and Relative Humidity in the main living and sleeping area were monitored at 10 minute intervals. The ASHRAE Standard 55 adaptive thermal comfort method was applied, which uses outdoor temperature to derive the optimum indoor comfort temperature. It was found that $29 \%$ of all living rooms and $31 \%$ of all bedrooms monitored during 2009 had more than $1 \%$ of summertime occupied hours outside the comfort zone recommended by the standard to achieve $90 \%$ acceptability. In 2010 , $37 \%$ of monitored living rooms and $49 \%$ of monitored bedrooms had more than $1 \%$ of summertime occupied hours outside this comfort zone. The findings of this study indicate that London dwellings face a significant risk of overheating under the current climate. Occupant exposure to excess indoor temperatures is likely to be exacerbated in the future if climate change adaptation strategies are not incorporated in Building Regulations, building design and retrofit.
\end{abstract}

Keywords: Overheating, Temperature, Monitoring, Housing, Dwellings, Climate change

\section{Nomenclature}

BREDEM: Building Research Establishment's Domestic Energy Model 
BS EN: British Standard European Norm

CaRB: Carbon Reduction in Buildings

DBT: Dry Bulb Temperature

EPC: Energy Performance Certificate

micro-CHP: micro Combined Heat and Power

MKEP: Milton Keynes Energy Park

PHPP: PassivHaus Planning Package

RdSAP: Reduced Standard Assessment Procedure

RH: Relative Humidity

SAP: Standard Assessment Procedure

SCAT: Smart Controls and Thermal Comfort

TM: Technical Memorandum

UHI: Urban Heat Island

UKCP09: UK Climate Change Projections 2009

VOC: Volatile Organic Compounds

Highlights

- Temperature and humidity were monitored in 122 London dwellings over two summers.

- Overheating was assessed using deterministic and adaptive thermal comfort criteria.

- A large number of London dwellings overheat even under the current climate.

- Overheating was found to be a significant problem in bedrooms. 
- Overheating in UK housing could be exacerbated in the future due to climate change. 
1. Introduction

\subsection{Background}

There is currently overwhelming scientific evidence and consensus that our climate is changing due to anthropogenic greenhouse gas emissions that have recently been the highest in history [1]. The frequency, intensity and duration of heatwaves are projected to increase worldwide [2], and recent research has suggested that the magnitude of increase might be even higher than initially estimated [3]. According to the UK Climate Change Projections 2009 (UKCP09), all UK regions are projected to become warmer, in particular during the summer period. Under the Medium emissions scenario, Southern England will experience the greatest rise in summer mean temperatures of up to $4.2{ }^{\circ} \mathrm{C}(2.2$ ${ }^{\circ} \mathrm{C}$ to $6.8^{\circ} \mathrm{C}$ ) by the end of the century compared to the $1961-1990$ baseline period [4]. It is predicted that the Met Office heatwave daytime external temperature threshold $\left(32^{\circ} \mathrm{C}\right)$ may be exceeded for one third of the summer period (June-August) in London by the middle of the century [5].

A well-established relationship exists between high temperatures and heat-related mortality risk at the population level. This was exemplified by the 2003 and 2006 European heatwaves, which led to disruptions and damages to industry, transport and infrastructure, and a significant increase in excess summer mortality, primarily amongst elderly and socially isolated individuals [6-8]. The exceptionally hot conditions in August 2003 are reported to have caused more than 30,000 excess deaths across Western Europe for the 10 days of the heatwave [9], 2,091 of which were reported in the UK, and 616 in London alone [10]. As a result, heat-related mortality prevention has become an issue of major public health concern in Europe and the UK [11-13]. Yet studies with detailed empirical data on indoor temperatures during summer as well as information on dwelling and occupant characteristics remain scarce.

Heat effects and consequent heat stress in urban areas are more severe than in rural ones. In addition to a warming climate, the risk of overheating is magnified in cities like London due to the Urban Heat Island (UHI) effect, a well-established phenomenon of inadvertent climate modification linked to urbanisation [14-16]. For example, during periods of hot weather, the highest heat-related 
mortality rates in the UK are observed in London [17]. It has been estimated that the proportion of excess heat-related deaths attributable to the UHI effect during a warm summer period in 2006 was around 38\% in outer London, 47\% in inner London and 47\% in central London [18].

The UK was the first country around the world to introduce a long-term legally binding framework to mitigate climate change. The Climate Change Act 2008 requires that UK emissions are reduced by at least $80 \%$ by 2050 , compared to 1990 levels [19]. As this emissions reduction is pursued in the building sector, improved Building Regulations will result in highly insulated and airtight building envelopes. Such building envelopes have the potential to overheat if not designed properly [20,21] and, in particular, if energy efficiency measures are not combined with appropriate passive cooling strategies [22-24]. For instance, studies have indicated that, even under the current climate, indoor overheating is a problem faced by $20 \%$ of UK homes [25-27].

As a consequence, frequent occurrences of indoor overheating could potentially result in maladaptation to a warming climate, such as high energy and high carbon cooling strategies that further contribute to climate change. A recent national survey of English housing found that air conditioning is currently very rare in domestic settings. Fixed or portable air conditioning units used in less than $3 \%$ of dwellings [28]. However, it has been suggested that air conditioning will become common in many new UK homes in the future [23]. A large expansion of the residential air conditioning market in the UK will inadvertently lead to increased energy consumption for cooling. This is further supported by the historical precedent of aggressive air conditioning penetration in the housing market of other countries, such as the USA [29]. If no other adaptation action is taken and if electricity is provided from the same fossil fuel sources that it currently is (i.e. if energy supply decarbonisation does not take place), the domestic cooling demand in the UK could markedly rise from the current negligible level, thus resulting in a considerable increase of carbon emissions from this source [30-33].

Reducing adverse effects of high indoor temperatures on the building energy consumption, comfort and health of its occupants should ideally be addressed by improved building performance achieved through passive cooling strategies [22-24]. The UK Building Regulations were historically aimed at reducing space heating energy consumption in winter. Whilst they currently include 
recommendations to limit solar heat gains, they do not adequately address the summer thermal performance of buildings [26]. In 2005, a revised version of the Standard Assessment Procedure (SAP), which is adopted by the UK Government as the method for calculating the energy performance of dwellings needed to meet Building Regulations, for the first time included an algorithm for summer overheating calculations in Appendix $P$ [34]. However, this is not integral in the SAP calculation as it does not affect the overall SAP rating. In addition, as a simplified, static algorithm, Appendix $P$ has significant limitations that have been highlighted by many authors $[26,35]$.

As a response to the issues outlined above, there has been considerable policy and research interest in the assessment of indoor overheating risk in UK housing in recent years [26]. A number of Government and industry reports have highlighted the need to enhance our understanding of building overheating risk and identify optimum solution pathways through long-term planning and improved building design $[13,26,36-42]$. The majority of academic studies that have attempted to quantify the extent and drivers of overheating risk in UK dwellings under the current and future climate, however, mainly rely on building performance modelling [23,35,43-55].

There is a clear lack of monitored temperature data from large, heterogeneous samples of UK dwellings and the majority of past monitoring campaigns focused on winter rather than summer thermal conditions. However, since the 2003 heatwave, there have been several monitoring studies of UK summer dwelling temperatures of varying sample sizes and heterogeneity in terms of dwelling and occupant characteristics, which are summarised in Table 1.

Existing studies are often characterised by small sample sizes and varying methodological approaches. Producing an accurate picture of the summer temperature profile of UK housing is hence challenging. However, some common patterns emerge from their findings. In agreement with the modelling studies cited earlier, monitoring studies have shown that dwelling type $[56,57,61,62,65,66]$ is an important modifying factor of indoor overheating risk. Purpose-built flats and structures that are highly exposed to solar gains appear to be more prone to excess temperatures. Construction age, a proxy for building fabric thermal characteristics, is another key predictor of heat risk $[25,27,61,66]$. It has been shown that 1960 s-70s and post-1990s properties are usually the warmest. There is evidence that newly built or retrofitted highly energy efficient dwellings [27,58] and, in particular, those built 
to PassivHaus standards $[67,68]$, may be at risk of summer overheating. There is also increasing recognition across the more recently published studies that occupant behaviour can influence overheating risk considerably and needs to be taken into account during building surveys [66-68]. 
1 Table 1 (a)

Summary of UK domestic overheating monitoring studies: study characteristics

\begin{tabular}{|c|c|c|c|c|c|c|c|c|}
\hline $\begin{array}{l}\text { Author name } \\
\text { and publication } \\
\text { year }\end{array}$ & $\begin{array}{l}\text { Measured } \\
\text { variables }\end{array}$ & $\begin{array}{l}\text { Overheating } \\
\text { criteria }\end{array}$ & $\begin{array}{l}\text { Monitoring } \\
\text { equipment }\end{array}$ & $\begin{array}{l}\text { Temporal } \\
\text { resolution }\end{array}$ & $\begin{array}{l}\text { Monitoring } \\
\text { period }\end{array}$ & $\begin{array}{l}\text { Summer } \\
\text { weather } \\
\text { conditions }\end{array}$ & Location & $\begin{array}{l}\text { Dwelling } \\
\text { sample size }\end{array}$ \\
\hline $\begin{array}{l}\text { Wright et al. } \\
2005 \text { [56] }\end{array}$ & $\overline{\mathrm{DBT}}$ & de Dear's model & iButton, HOBO & $\begin{array}{l}15 \text { minutes }-1 \\
\text { hour }\end{array}$ & August 2003 & 2003 heatwave & $\begin{array}{l}\text { London, } \\
\text { Manchester }\end{array}$ & $\overline{9}$ \\
\hline $\begin{array}{l}\text { Firth et al. } 2007 \\
\text { [57] }\end{array}$ & DBT & $\begin{array}{l}\text { CIBSE Guide A } \\
(2007)\end{array}$ & HOBO pendant & 30 minutes & $\begin{array}{l}\text { July } 2006- \\
\text { April } 2007\end{array}$ & 2006 heatwave & Leicester & 62 \\
\hline $\begin{array}{l}\text { Summerfield et } \\
\text { al. } 2007 \text { [58] }\end{array}$ & $\begin{array}{l}\text { DBT, RH, } \\
\text { energy use }\end{array}$ & - & HOBO U12-012 & 10-30 minutes & $\begin{array}{l}\text { February } 2005- \\
\text { July } 2006\end{array}$ & Mild summer & Milton Keynes & 15 \\
\hline $\begin{array}{l}\text { Young et al. } \\
2007 \text { [59], } \\
\text { Pathan et al. } \\
2008 \text { [60] }\end{array}$ & DBT & - & TinyTag & 5 minutes & $\begin{array}{l}\text { July - } \\
\text { September } 2004\end{array}$ & Mild summer & $\begin{array}{l}\text { South East of } \\
\text { England }\end{array}$ & 13 \\
\hline $\begin{array}{l}\text { Firth and Wright } \\
2008 \text { [61] }\end{array}$ & DBT & $\begin{array}{l}\text { CIBSE Guide A } \\
\text { (2007) }\end{array}$ & HOBO pendant & 45 minutes & $\begin{array}{l}\text { July - August } \\
2007\end{array}$ & Mild summer & England & 224 \\
\hline $\begin{array}{l}\text { Beizaee et al. } \\
2013 \text { [25] }\end{array}$ & DBT & $\begin{array}{l}\text { CIBSE Guide A } \\
\text { (2007), BS EN } \\
15251\end{array}$ & HOBO pendant & 45 minutes & $\begin{array}{l}\text { July } 2007- \\
\text { March } 2008\end{array}$ & Mild summer & England & 193 \\
\hline $\begin{array}{l}\text { Hulme et al. } \\
2013 \text { [27] }\end{array}$ & DBT & $\begin{array}{l}\text { RdSAP } \\
\text { Appendix P, } \\
\text { occupant self- } \\
\text { reported } \\
\text { assessments } \\
\end{array}$ & TinyTag & 20 minutes & $\begin{array}{l}\text { February } 2011 \text { - } \\
\text { January } 2012\end{array}$ & $\begin{array}{l}\text { Hot spell in late } \\
\text { June } 2011\end{array}$ & England & 823 \\
\hline $\begin{array}{l}\text { Lomas and Kane } \\
2013 \text { [62], } \\
\text { Oraio- poulos et } \\
\text { al. } 2015 \text { [63] }\end{array}$ & $\begin{array}{l}\text { DBT, energy } \\
\text { use }\end{array}$ & BS EN 15251 & HOBO pendant & 1 hour & $\begin{array}{l}\text { July } 2009- \\
\text { February } 2010\end{array}$ & Mild summer & Leicester & 230 \\
\hline Pana 2013 [64] & DBT & $\begin{array}{l}\text { CIBSE Guide A } \\
\text { (2007), BS EN } \\
15251\end{array}$ & TinyTag & 5 minutes & June - July 2013 & 2013 heatwave & Dunblane & 4 \\
\hline $\begin{array}{l}\text { Baborska- } \\
\text { Narozny et al. } \\
2015 \text { [65] }\end{array}$ & $\begin{array}{l}\text { DBT, RH, } \\
\text { energy use }\end{array}$ & $\begin{array}{l}\text { CIBSE Guide A } \\
(2007)\end{array}$ & iButton & 30 minutes & $\begin{array}{l}\text { April } 2013- \\
\text { April } 2014\end{array}$ & 2013 heatwave & Leeds & $\begin{array}{r}20 \\
\text { (2 case studies) }\end{array}$ \\
\hline
\end{tabular}




\begin{tabular}{|c|c|c|c|c|c|c|c|c|}
\hline $\begin{array}{l}\text { Mavrogianni et } \\
\text { al. } 2015 \text { [66] }\end{array}$ & DBT, RH & $\begin{array}{l}\text { CIBSE Guide A } \\
(2007), \text { BS EN } \\
15251\end{array}$ & HOBO U12-012 & 15 minutes & $\begin{array}{l}\text { July - } \\
\text { September } 2013\end{array}$ & 2013 heatwave & London & 8 \\
\hline $\begin{array}{l}\text { Morgan et al. } \\
2015 \text { [67] }\end{array}$ & $\begin{array}{l}\text { DBT, } \mathrm{RH}, \mathrm{CO}_{2} \\
\text { levels, window } \\
\text { opening }\end{array}$ & $\begin{array}{l}\text { CIBSE Guide A } \\
\text { (2007), PHPP }\end{array}$ & $\begin{array}{l}\text { (remote } \\
\text { monitoring) }\end{array}$ & 5 minutes & $\begin{array}{l}2 \text { years } \\
\text { including July } \\
2013\end{array}$ & 2013 heatwave & Scotland & 26 \\
\hline $\begin{array}{l}\text { Tabatabaei } \\
\text { Sameni et al. } \\
2015 \text { [68] }\end{array}$ & $\begin{array}{l}\text { DBT, } \mathrm{RH}, \mathrm{CO}_{2} \\
\text { levels, VOC } \\
\text { levels }\end{array}$ & $\begin{array}{l}\text { CIBSE TM52, } \\
\text { PHPP }\end{array}$ & Not provided & Not provided & $\begin{array}{l}\text { Summers of } \\
2011,2012, \\
2013\end{array}$ & 2013 heatwave & Coventry & 23 \\
\hline $\begin{array}{l}\text { Toledo et al. } \\
2016 \text { [69] }\end{array}$ & DBT, RH & $\begin{array}{l}\text { CIBSE Guide A } \\
(2007)\end{array}$ & HOBO & 10 minutes & $\begin{array}{l}\text { June - August } \\
2015\end{array}$ & $\begin{array}{l}\text { Hot spell in late } \\
\text { June } 2015\end{array}$ & $\begin{array}{l}\text { Leicester, } \\
\text { Sandiacre, York }\end{array}$ & 4 \\
\hline $\begin{array}{l}\text { Vellei et al. } \\
2016 \text { [70] }\end{array}$ & $\begin{array}{l}\text { DBT, } \mathrm{RH}, \mathrm{CO}_{2} \\
\text { levels, window } \\
\text { opening }\end{array}$ & CIBSE TM52 & $\begin{array}{l}\text { DS18B20 } \\
\text { temperature } \\
\text { sensor, RHT03 } \\
\text { humidity sensor, } \\
\text { K30 Senseair } \\
\mathrm{CO}_{2} \text { sensor, HC- } \\
\text { SRS01 PIR } \\
\text { infrared motion } \\
\text { camera }\end{array}$ & 10-30 minutes & $\begin{array}{l}\text { May-September } \\
2014\end{array}$ & Mild summer & Exeter & 46 \\
\hline
\end{tabular}

Table 1 (b)

Summary of UK domestic overheating monitoring studies: study characteristics

\begin{tabular}{llllll}
\hline $\begin{array}{l}\text { Author name and } \\
\text { publication year }\end{array}$ & Dwelling type & $\begin{array}{l}\text { Monitored } \\
\text { rooms }\end{array}$ & $\begin{array}{l}\text { Building } \\
\text { survey? }\end{array}$ & $\begin{array}{l}\text { Occupant } \\
\text { behaviour or } \\
\text { comfort } \\
\text { survey? }\end{array}$ & Main findings \\
\hline $\begin{array}{l}\text { Wright et al. } \\
2005 \text { [56] }\end{array}$ & Varied sample & $\begin{array}{l}\text { Living room, } \\
\text { bedrooms, } \\
\text { kitchens }\end{array}$ & Yes & No & $\begin{array}{l}\text { Large intra-dwelling temperature differences were observed. Differences of up to } 5{ }^{\circ} \mathrm{C} \\
\text { between internal and external night temperatures were measured. }\end{array}$ \\
\hline $\begin{array}{l}\text { Firth et al. 2007 } \\
\text { [57] }\end{array}$ & $\begin{array}{l}\text { Mainly retrofitted } \\
\text { Victorian houses }\end{array}$ & $\begin{array}{l}\text { Living room, } \\
\text { bedroom }\end{array}$ & Yes & Yes & Large intra-dwelling temperature differences of up to $5{ }^{\circ} \mathrm{C}$ were observed. \\
\hline $\begin{array}{l}\text { Summerfield et } \\
\text { al. 2007 [58] }\end{array}$ & $\begin{array}{l}\text { Low energy } \\
\text { dwellings }\end{array}$ & $\begin{array}{l}\text { Multiple } \\
\text { rooms }\end{array}$ & Yes & Yes & $\begin{array}{l}\text { Large differences between internal and external temperatures were observed, which } \\
\text { might indicate increased summer overheating risk. }\end{array}$ \\
\hline Young et al. 2007 & Mainly air- & Air- & No & Yes & Air-conditioning units were switched on when room temperatures reached 24-25 ${ }^{\circ} \mathrm{C}$
\end{tabular}




\begin{tabular}{|c|c|c|c|c|c|}
\hline $\begin{array}{l}\text { [59], Pathan et al. } \\
2008 \text { [60] }\end{array}$ & $\begin{array}{l}\text { conditioned } \\
\text { dwellings }\end{array}$ & $\begin{array}{l}\text { conditioned } \\
\text { rooms }\end{array}$ & & & and they operated for 5 hours during the day and 7 hours during the night on average. \\
\hline $\begin{array}{l}\text { Firth and Wright } \\
2008[61]\end{array}$ & Varied sample & $\begin{array}{l}\text { Living room, } \\
\text { bedroom }\end{array}$ & No & Yes & $\begin{array}{l}\text { Purpose-built flats and mid-terraced houses were found to be warmer. Newly built } \\
\text { post-1990 dwellings were also found to be warmer, whereas older pre-1919 dwellings } \\
\text { were colder. }\end{array}$ \\
\hline $\begin{array}{l}\text { Beizaee et al. } \\
2013[25]\end{array}$ & Varied sample & $\begin{array}{l}\text { Living room, } \\
\text { bedroom }\end{array}$ & No & Yes & $\begin{array}{l}\text { One fifth of bedrooms were found to exceed the CIBSE Guide A (2007) overheating } \\
\text { criterion. Newly-built post-1990 dwellings were also found to be warmer, whereas } \\
\text { older pre-1919 dwellings were colder. }\end{array}$ \\
\hline $\begin{array}{l}\text { Hulme et al. } 2013 \\
\text { [27] }\end{array}$ & $\begin{array}{l}\text { Nationally } \\
\text { representative } \\
\text { sample }\end{array}$ & $\begin{array}{l}\text { Living room, } \\
\text { bedroom, } \\
\text { hallway }\end{array}$ & Yes & Yes & $\begin{array}{l}\text { One fifth of dwellings were reported by occupants to overheat during the summer. } \\
\text { More energy efficient (SAP rating above 70), modern } 1975-80 \text { and newly built post- } \\
1990 \text { dwellings were also found to be warmer, whereas older pre-1919 dwellings were } \\
\text { cooler. }\end{array}$ \\
\hline $\begin{array}{l}\text { Lomas and Kane } \\
2013 \text { [62], } \\
\text { Oraiopoulos et al. } \\
2015 \text { [63] }\end{array}$ & Varied sample & $\begin{array}{l}\text { Living room, } \\
\text { bedroom }\end{array}$ & Yes & Yes & $\begin{array}{l}\text { Dwellings occupied by older residents and purpose-built flats were found to be } \\
\text { warmer. Solid walled dwellings were found to be cooler. }\end{array}$ \\
\hline Pana 2013 [64] & $\begin{array}{l}\text { Newly built } \\
\text { dwellings }\end{array}$ & Bedroom & No & Yes & Orientation is a significant modifying factor of overheating. \\
\hline $\begin{array}{l}\text { Baborska- } \\
\text { Narozny et al. } \\
2015[65]\end{array}$ & $\begin{array}{l}\text { Social housing, } \\
\text { newly purpose-built } \\
\text { flats }\end{array}$ & $\begin{array}{l}\text { Living room, } \\
\text { bedroom, } \\
\text { bathroom }\end{array}$ & Yes & Yes & Dwellings at higher floor levels and without shading were found to be warmer. \\
\hline $\begin{array}{l}\text { Mavrogianni et } \\
\text { al. } 2015 \text { [66] }\end{array}$ & $\begin{array}{l}\text { Social housing, } \\
\text { purpose-built flats }\end{array}$ & $\begin{array}{l}\text { Living room, } \\
\text { bedroom }\end{array}$ & Yes & Yes & Modern 1960s high-rise purpose-built flats were found to be warmer. \\
\hline $\begin{array}{l}\text { Morgan et al. } \\
2015[67]\end{array}$ & $\begin{array}{l}\text { Newly built, low } \\
\text { energy, PassivHaus } \\
\text { dwellings }\end{array}$ & $\begin{array}{l}\text { Living room, } \\
\text { bedroom }\end{array}$ & No & Yes & $\begin{array}{l}\text { Bedrooms were found to be warmer compared to living rooms. Occupant behaviour is } \\
\text { a significant modifying factor of overheating. }\end{array}$ \\
\hline $\begin{array}{l}\text { Tabatabaei } \\
\text { Sameni et al. } \\
2015 \text { [68] }\end{array}$ & $\begin{array}{l}\text { Social housing, } \\
\text { PassivHaus } \\
\text { dwellings }\end{array}$ & Living room & Yes & Yes & $\begin{array}{l}\text { Two thirds of dwellings were found to exceed their design criteria. Occupant } \\
\text { behaviour is a significant modifying factor of overheating. }\end{array}$ \\
\hline $\begin{array}{l}\text { Toledo et al. } \\
2016 \text { [69] }\end{array}$ & $\begin{array}{l}\text { Newly retrofitted, } \\
\text { highly insulated } \\
\text { houses }\end{array}$ & $\begin{array}{l}\text { Multiple } \\
\text { rooms }\end{array}$ & Yes & Yes & $\begin{array}{l}\text { Mechanical ventilation is not effective for summer cooling. Houses where natural } \\
\text { ventilation was applied were kept colder. }\end{array}$ \\
\hline $\begin{array}{l}\text { Vellei et al. } 2016 \\
\text { [70] }\end{array}$ & $\begin{array}{l}\text { Social housing, } \\
\text { newly retrofitted } \\
\text { dwellings }\end{array}$ & $\begin{array}{l}\text { Living room, } \\
\text { bedroom, } \\
\text { kitchen }\end{array}$ & No & Yes & $\begin{array}{l}\text { Dwellings with exposed roofs were found to be warmer. Bedrooms and kitchens were } \\
\text { found to be warmer compared to living rooms. }\end{array}$ \\
\hline
\end{tabular}


The studies summarised above have improved our knowledge of actual summer performance of

4 UK dwellings. However, few of them have been carried out on large housing samples over long periods of time or have captured adequate information on building fabric characteristics and occupant behaviour. The present study adds to this growing body of literature by evaluating the performance of a large sample of urban dwellings over two summer periods.

This paper investigates indoor temperatures measured in 122 London dwellings that were monitored at 10 minute intervals during the summer of 2009 and 2010. The study included an interview questionnaire survey of occupant socioeconomic status, ventilation patterns, appliance use, and other factors. Indoor temperatures were analysed to determine the extent of indoor overheating using existing assessment criteria based on: (a) deterministic, fixed thresholds, as exemplified by the $7^{\text {th }}$ edition of Environmental Design Guide $A$ by the Chartered Institution of Building Services Engineers (CIBSE) [71] and a recent report by the Zero Carbon Hub (ZCH) [72], and (b) the adaptive thermal comfort approach, as defined in the American National Standards Institute - American Society of Heating, Refrigerating, and Air-Conditioning Engineers (ANSI/ASHRAE) Standard 55$2013[73]$.

The main aim of the paper is to offer an overall assessment of the extent of indoor overheating experienced in London dwellings over the entire monitoring period with a focus on the modifying effect of building fabric characteristics. The influence of occupant behaviour on overheating risk in the monitored dwellings was explored in a parallel paper [74]. The thermal performance of a smaller subsample during the particularly hot spell that occurred in the beginning of the 2009 summer was also analysed in an earlier publication [75].

2.1 Indoor and outdoor thermal monitoring, building physical survey and occupant questionnaire survey 
The sampling frame of the study comprised properties occupied by staff (academic and support) 2 and graduate students of the Bartlett School of Graduate Studies (BSGS), University College London 3 (UCL). Households were recruited in early 2009 via a call for participation in a summertime indoor 4 thermal monitoring, building physical survey and occupant questionnaire survey. The call was 5 circulated through the department's mailing list and recipients of the email were encouraged to 6 forward it further. Participants were offered a free energy report in the form of an Energy 7 Performance Certificate (EPC) at the end of the survey [34]. No additional incentive to take part was offered.

For financial and logistic reasons, a sample of 111 participants was selected from a pool of around 10350 volunteers. The ability to select a subset of participants from a considerably larger pool of 11 volunteers provided an opportunity to choose a sample of dwellings that provided a good spread of 12 locations throughout London, shown in Figure 1. Various types of built forms were represented 13 appropriately. Four main dwelling types (detached, semi-detached, mid-terraced house and purposebuilt flat) were chosen within each postcode area across the Greater London Area (GLA), where this was possible. The participating dwellings were further divided into two main subcategories (heavyweight and lightweight construction), so that there would be at least 10 dwellings in each category. In addition, 10 properties were selected from the sample, once again to achieve good geographical coverage through Greater London, where external temperature was also measured. Of these, reliable data were obtained from 8 external data loggers, shown in Figure 2. 


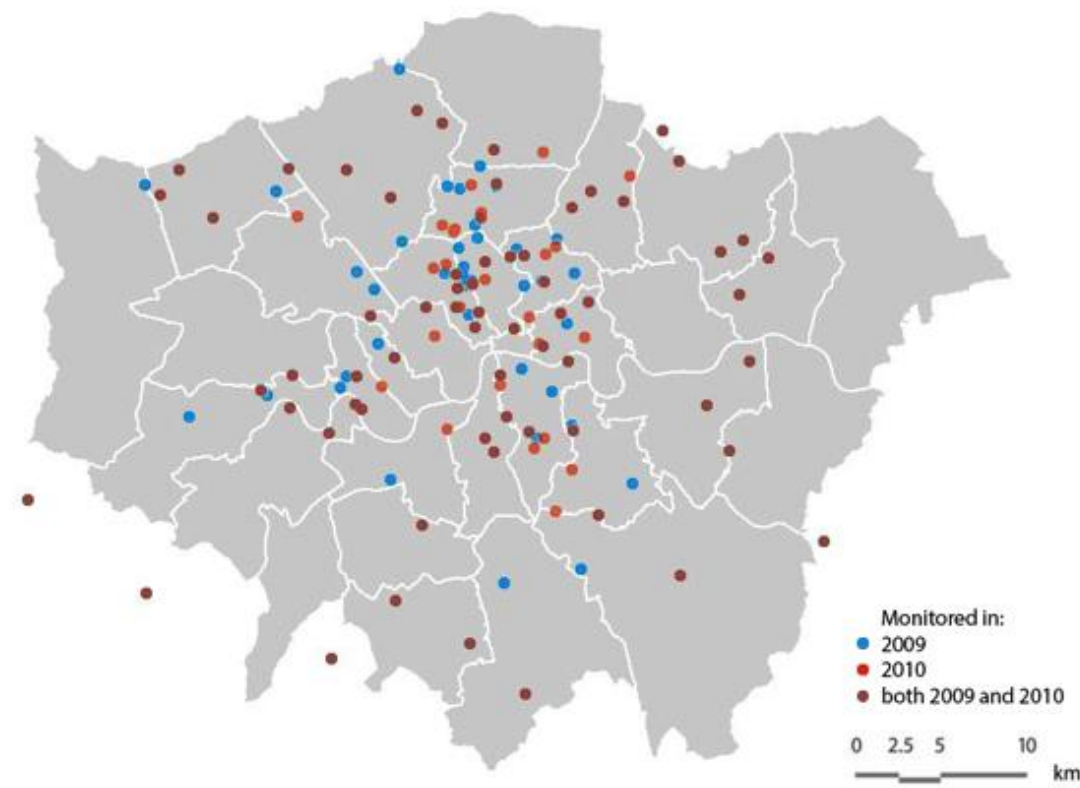

Fig. 1. Locations of dwellings with indoor temperature data loggers installed

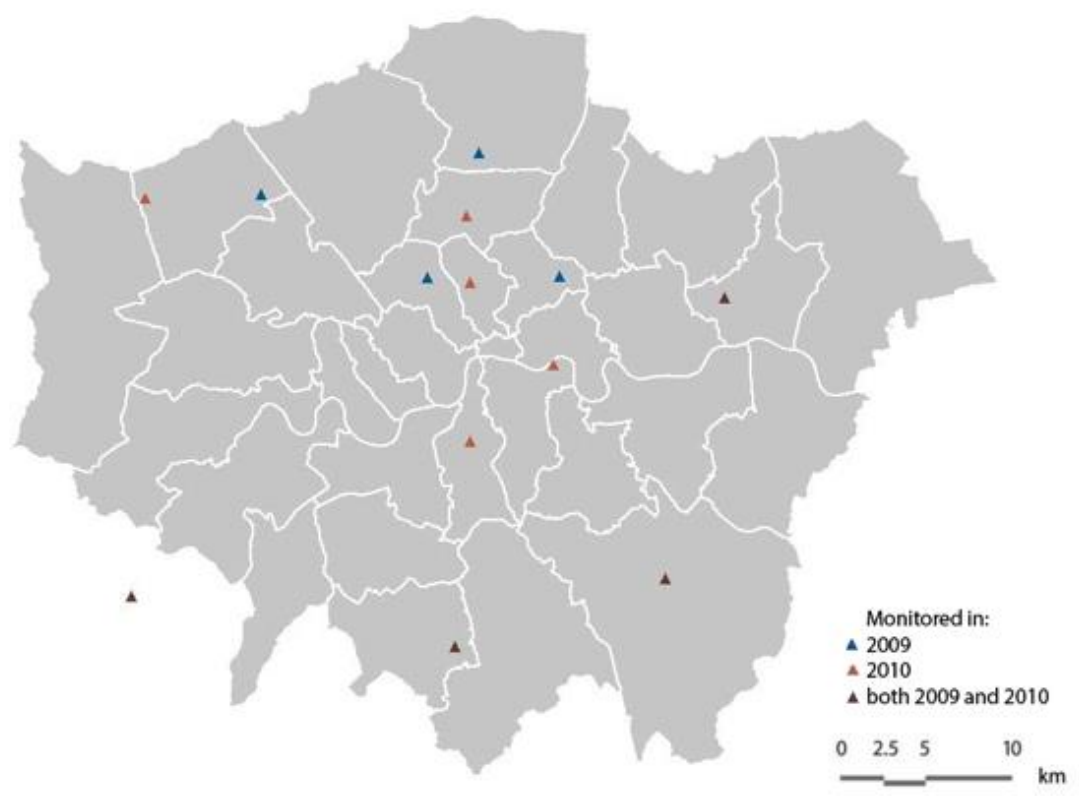

Fig. 2. Locations of dwellings with outdoor temperature data loggers installed 
2 2009. Of these, 101 dwellings had reliable monitoring data. Full monitoring and survey data were 3 collected for 94 living rooms and 93 bedrooms, which were analysed for this paper. All participants 4 were requested to take part in another round of monitoring in the summer of 2010 . Of the households 5 that took part in 2009 survey, 63 consented to participate again during the summer of 2010 and reliable monitoring and survey data were collected in all of them. A further 30 new households were recruited to increase the sample size, of which 28 returned data that could be analysed. The dwellings where indoor and outdoor monitoring was undertaken in 2010 are shown in Figures 1 and 2, respectively. Full data were collected for 122 unique dwellings for at least one summer. The sample distribution by monitoring period is presented in Table 2 and the breakdown by dwelling type and construction age is provided in Table 3 below.

Table 2

Sample distribution during the two monitoring periods.

\begin{tabular}{lrrrr}
\hline Room & 2009 and 2010 & 2009 only & 2010 only & Total \\
\hline Living room & 63 & 38 & 28 & 129
\end{tabular}

Bedroom $\quad 63 \quad 36 \quad 28 \quad 127$

Table 3

Sample distribution by dwelling type and construction age.

\begin{tabular}{|c|c|c|c|c|c|c|}
\hline & $\begin{array}{r}\text { Mid- or end- } \\
\text { terraced }\end{array}$ & $\begin{array}{r}\text { Semi- } \\
\text { detached }\end{array}$ & Detached & $\begin{array}{l}\text { Purpose- } \\
\text { built flat }\end{array}$ & $\begin{array}{r}\text { Converted } \\
\text { flat } \\
\end{array}$ & Total \\
\hline Pre 1900 & 21 & 3 & & 3 & 22 & 49 \\
\hline 1900-1929 & 7 & 3 & & 2 & 5 & 17 \\
\hline $1930-1949$ & 6 & 5 & 4 & 5 & 1 & 21 \\
\hline $1950-1966$ & 2 & 3 & 1 & 1 & & 7 \\
\hline $1967-1975$ & 3 & & 1 & 10 & & 14 \\
\hline $1976-1982$ & & 1 & & 1 & 1 & 3 \\
\hline 1983-1990 & & 1 & & 3 & & 4 \\
\hline 1991-1995 & & & 1 & 2 & & 3 \\
\hline $1996-2002$ & & & 1 & 3 & & 4 \\
\hline 2003-2006 & & & & 5 & & 5 \\
\hline Post 2006 & & & & 2 & & 2 \\
\hline Total & 39 & 16 & 8 & 37 & 29 & 129 \\
\hline
\end{tabular}

21 Figure 3 compares the breakdown of the study sample by dwelling type with that of the 2011

22 Census [76] across Greater London. The sample of the present study appears to have a relatively

higher proportion of terraced houses and a lower proportion of semi-detached houses and purpose- 
1 built flats. Nevertheless, it broadly matches the Census distribution. It should be noted that, according

2 to the Census, $12 \%$ of all London dwellings are converted flats but their distribution by dwelling type

3 is unknown. In addition, around $2 \%$ of all London dwellings are in a commercial building, in hotels or

4 over a shop, and around $0.1 \%$ of all dwellings are classified as caravans or other mobile or temporary

5 dwellings. These categories were not represented in this study since they make up a very small fraction of the building stock

Two data loggers (HOBO U12-012) [77] were placed in each dwelling measuring Dry Bulb

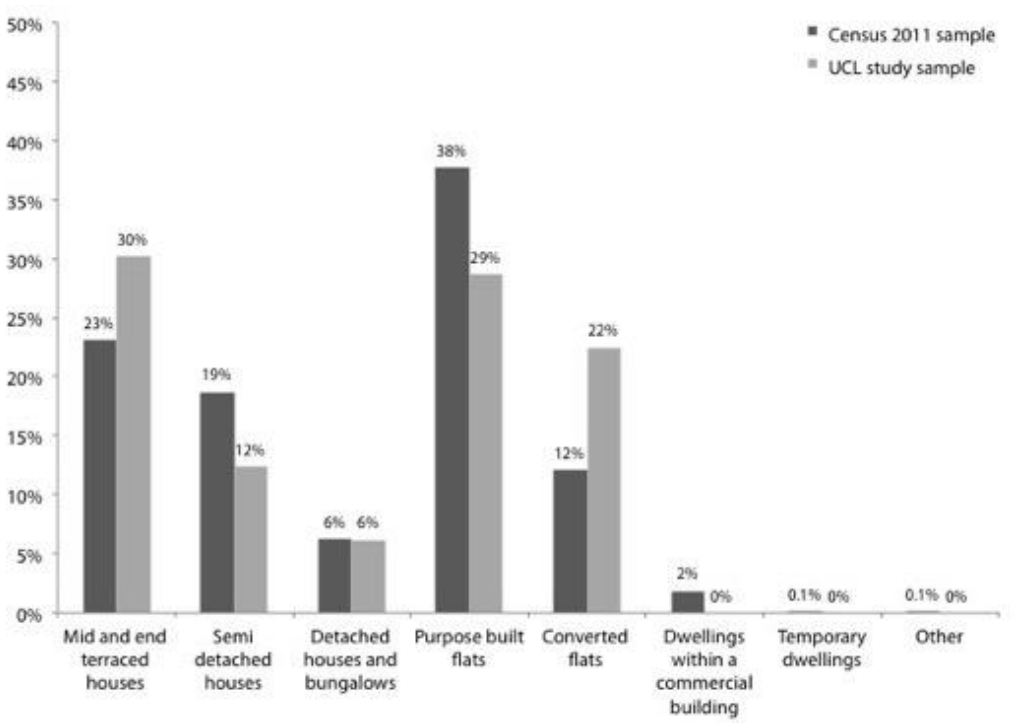

Fig. 3. Comparison of distribution of dwelling types within the 2011 London Census and the present study samples

Temperature (DBT, ${ }^{\circ} \mathrm{C}$ ) and Relative Humidity $(\mathrm{RH}, \%)$ at 10 -minute intervals in the main living area (where the household spent most of their time during day) and in the main sleeping area (where the participant slept during most nights). The loggers were placed by the participants themselves

following detailed instructions that were provided to them. In particular, they were asked to place 
loggers at around eye level, away from direct sunlight and away from heating sources like radiators,

2 light bulbs, TV sets or other electronic equipment.

3 For the external measurements, HOBO U12-012 loggers were mounted on the garden fence of 4 dwellings, housed in a solar radiation shield (Stevenson screen). The actual monitoring period varied 5 across dwellings based on when each participant set up their data loggers. Most dwellings were, 6 however, monitored between July and August as a minimum. All data loggers used for the survey were calibrated at $3{ }^{\circ} \mathrm{C}$ intervals from 10 to $31{ }^{\circ} \mathrm{C}$, and corresponding $\mathrm{RH}$ from $40 \%$ to $75 \%$ in $5 \%$ intervals in the BSGS thermal chamber. Results from the calibration test showed that all loggers had temperature accuracy within the range specified by the manufacturer, which is $\pm 0.35{ }^{\circ} \mathrm{C}$ with a range of $0-50{ }^{\circ} \mathrm{C}$.

Extensive data about the dwellings and their occupants were gathered at the end of the monitoring period. This included a face-to-face questionnaire survey to gather information on the occupants' socioeconomic status, use of appliances and summertime ventilation habits. The questionnaire used in this study was a modified version of a form initially developed by the Carbon Reduction in Buildings (CaRB) research project [78]. An EPC building physical survey was also carried out. This included the generation of the energy and environmental impact rating of the dwelling using Reduced SAP (RdSAP) 2005 [34]. The procedure used for SAP calculations was based on the Building Research Establishment's Domestic Energy Model (BREDEM) [79].

\subsection{Indoor overheating assessment}

\subsubsection{Overview of existing criteria}

There has been little generally accepted UK guidance on benchmark summer peak temperatures or overheating criteria for use in the design of non-air conditioned buildings or spaces, with the exception of schools. This was discussed in a recent detailed evidence review on existing overheating definitions and criteria undertaken as part of the ZCH's project 'Tackling Overheating in Buildings' $[26,80]$. CIBSE has undertaken considerable consultation and research on the impact of climate change on the indoor environment and on weather data. Existing recommendations for the assessment 

based on the adaptive thermal comfort approach. Both approaches have been used for the assessment of indoor overheating levels in the monitored sample of the present study.

It is worth noting that both the deterministic and adaptive criteria discussed below refer to operative temperatures. A limitation of this study, shared with the majority of UK indoor overheating monitoring studies in the literature, is that dry bulb temperature rather than operative temperature was measured due to the increased complexity and cost associated with mean radiant temperature monitoring. It is often assumed that the difference between dry bulb and mean radiant temperature, and hence the difference between dry bulb and operative temperature, is marginal in well insulated rooms and locations away from direct solar radiation or other indoor sources of radiation [81]. However, this may not be the case for the less well insulated dwellings in the monitoring sample. In addition, a recent study found that the differences between air and mean radiant temperature are negligible during most periods, but for warmer temperatures mean radiant temperature could be higher than air temperature by up to $1.3 \mathrm{~K}$ [82]. This suggests that the part of the present study that focuses on summer thermal comfort during the hot spells of the monitoring period may underestimate indoor heat stress. It is, thus, recommended that future work combines mean radiant and air temperatures in order to produce a more accurate picture of indoor overheating risk in dwellings.

\subsubsection{Criteria based on fixed thresholds}

Existing deterministic summer thermal comfort models and associated thresholds, such as the ones included in CIBSE's $7^{\text {th }}$ edition Guide A [71], are based on data from controlled climate chamber studies under steady state conditions, or intuition and expert knowledge and are not usually underpinned by robust field data. They have, thus, been criticised as they are mainly applicable to particular combinations of indoor thermal conditions, occupant metabolic rate, and clothing insulation levels. In addition, single temperature exceedance thresholds do not provide a measure of the severity of the overheating problem. Nonetheless, this approach also has some considerable advantages, which were highlighted in a recent discussion paper emanating from the $\mathrm{ZCH}$ project [72]. A key advantage 
2 the housing industry. summer peak temperatures and overheating criteria for use in design for non-air conditioned 5 dwellings.

10 Table 4

11 General summer indoor comfort temperatures, benchmark summer peak temperatures and overheating criteria 12 for non-air conditioned dwellings in the UK, assuming warm summer conditions (CIBSE Guide A $7^{\text {th }}$ edition 13 [71]).

\begin{tabular}{lrrr}
\hline Space & $\begin{array}{r}\text { Operative } \\
\text { temperature for } \\
\text { indoor comfort in } \\
\text { summer }\left({ }^{\circ} \mathrm{C}\right)\end{array}$ & $\begin{array}{r}\text { Benchmark summer } \\
\text { peak operative } \\
\text { temperature }\left({ }^{\circ} \mathrm{C}\right)\end{array}$ & Overheating criterion \\
\hline $\begin{array}{l}\text { Living room } \\
\text { Bedroom }\end{array}$ & 25 & 28 & $1 \%$ annual occupied hours over $28{ }^{\circ} \mathrm{C}$ \\
& 23 & 26 & $1 \%$ annual occupied hours over $26{ }^{\circ} \mathrm{C}$, sleep \\
may be impaired above $24{ }^{\circ} \mathrm{C}$
\end{tabular}

A simpler criterion has been recommended by the $\mathrm{ZCH}$ [72], according to which, at the design stage of a project, bedrooms should be capable of not exceeding $26{ }^{\circ} \mathrm{C}$ for more than a specified percentage of occupied hours. Using two temperature benchmarks is considered helpful as it is possible that both shorter but intensely hot periods, and more prolonged warm periods can have equally detrimental health effects on occupants. For the purposes of this study, overheating was deemed to occur when indoor monitored temperatures were above $28{ }^{\circ} \mathrm{C}$ and $26{ }^{\circ} \mathrm{C}$ in the living room and bedroom, respectively, for more than $1 \%$ of total occupied hours. As an additional criterion, the number of times temperatures rose above $25{ }^{\circ} \mathrm{C}$ and $24{ }^{\circ} \mathrm{C}$ in the living room and bedroom, respectively, for more than $5 \%$ of occupied hours were also considered, in line with the analysis carried out in CIBSE 'TM36 - Climate Change and the Indoor Environment: Impacts and Adaptation' 
The study did not collect data on actual occupancy patterns throughout the monitoring period (e.g.

using occupant diaries). Therefore, it was not possible to use the actual occupancy hours in the calculations. CIBSE or other relevant guidelines do not define standard occupied hours for indoor overheating assessment. Therefore, for the purposes of this study, 8 am to 8 pm was considered as occupied hours for the living areas, while $8 \mathrm{pm}$ to 8 am was considered as occupied hours for bedrooms. This is consistent with the standard occupancy assumptions utilised in previous papers that have analysed this monitoring dataset [74-75].

\subsubsection{Criteria based on the adaptive thermal comfort approach}

In recent years, there has been a shift from the use of deterministic thresholds to the adoption of adaptive criteria for the evaluation of thermal comfort conditions in free running buildings. The adaptive thermal comfort approach defines comfort temperature bands as a function of outdoor ambient temperatures [84], and it is widely recognised as a more rigorous solution to the assessment of indoor overheating.

There are two commonly used adaptive thermal comfort standards: (a) the ANSI/ASHRAE Standard 55-2013 [73], which was formulated based on an extensive field study data from a wide range of building types (including office, residential and industrial buildings) and locations around the world, the RP-884 database [85], and (b) the British Standard (BS) European Norm (EN) 15251:2007 [86], which is based on the Smart Controls and Thermal Comfort (SCATs) monitoring study carried out in a total of 26 office buildings in five EU countries $[87,88]$.

BS EN 15251 has recently been embedded in UK guidance, such as CIBSE's 'TM52 - The Limits of Thermal Comfort: Avoiding Overheating in European Buildings' and the recently published $8^{\text {th }}$ edition of Guide A. However, the evidence base that underpins its calculations consists of a pooled assessment of field data collected entirely in office buildings. Thus, it may not be well suited for domestic buildings. For example, the adaptive capacity of people in homes is likely to vary greatly to that of office workers. Studies have demonstrated that occupants may tolerate a greater range of environmental conditions in residential settings [89]. 
2 uses the monthly mean external temperature to calculate the comfort indoor temperature, whereas the

3 latter is based on a weighted running mean of external temperature. ASHRAE Standard 55 was also

4 developed for naturally ventilated buildings, whereas BS EN 15251 is deemed appropriate for free-

5 running buildings in general.

6 Taking the above into consideration, the ASHRAE Standard 55 was used in the present study for 7 the assessment of overheating in the predominantly naturally ventilated monitored dwellings. It 8 provides a simple formula for the calculation of the comfort indoor temperature, provided in Equation

9 (1) below:

$T_{c}=0.31 \times T_{o}+17.8$

11 where

$T_{c} \quad: \quad$ Indoor optimum comfort operative temperature $\left({ }^{\circ} \mathrm{C}\right)$

$T_{o} \quad: \quad$ Outdoor monthly mean air temperature $\left({ }^{\circ} \mathrm{C}\right)$

It is suggested that a latitude of $\pm 2.5{ }^{\circ} \mathrm{C}$ either side of the optimum temperature $\left(5^{\circ} \mathrm{C}\right.$ band) is consistent with $90 \%$ acceptability in naturally ventilated buildings for mean external temperatures between 10.0 and $33.5^{\circ} \mathrm{C}$. For $80 \%$ acceptability the limits can be relaxed to $\pm 3.5^{\circ} \mathrm{C}$ either side of the optimum temperature $\left(7^{\circ} \mathrm{C}\right.$ band). The $90 \%$ acceptability range of indoor optimum comfort operative temperature was chosen for the present study in line with previous London overheating studies that have used ASHRAE Standard 55 [56].

The ASHRAE Standard 55 only describes the process to derive the comfort indoor temperature range and does not include exceedance thresholds above which a building would be deemed to overheat. In order to be consistent with the CIBSE fixed overheating thresholds, a dwelling with more than $1 \%$ of occupied hours above $T_{c}+2.5{ }^{\circ} \mathrm{C}$ was considered overheated for the purpose of this 23 analysis. 
2 temperatures for each month during the monitoring period. Table 5 lists recorded outdoor monthly 3 mean air temperatures for June, July, August and September 2009 and 2010. Monitored data were not 4 available for all days in June; monthly mean temperatures for June were, therefore, obtained from Met

5 Office observations at London Heathrow [90], summary climate data from which are summarised in 6 Table 6 . Table 5 also lists the indoor optimum comfort operative temperatures calculated from the outdoor monthly mean air temperature and two comfort bands $\left( \pm 2.5^{\circ} \mathrm{C}\right.$ and $\pm 3.5^{\circ} \mathrm{C}$. corresponding to $90 \%$ and $80 \%$ acceptability, respectively).

Table 5

Indoor optimum comfort operative temperature ranges based on the ASHRAE Standard 55 [73]

and external air temperature data in London Heathrow provided by the Met Office [90] for June 2009 and 2010 and external data loggers for all other months.

\begin{tabular}{|c|c|c|c|c|c|}
\hline 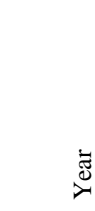 & $\begin{array}{l}\bar{D} \\
\sum_{0}^{0}\end{array}$ & 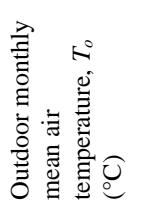 & 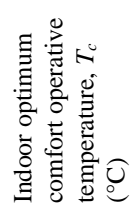 & 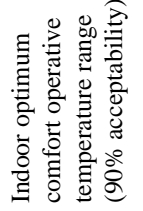 & 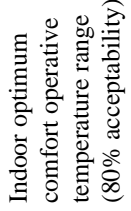 \\
\hline 2009 & 6 & 17.3 & 23.2 & $20.7-25.7$ & $19.7-26.7$ \\
\hline 2009 & 7 & 18.3 & 23.5 & $21.0-26.0$ & $20.0-27.0$ \\
\hline 2009 & 8 & 18.7 & 23.6 & $21.1-26.1$ & $20.1-27.1$ \\
\hline 2009 & 9 & 15.8 & 22.7 & $20.2-25.2$ & $19.2-26.2$ \\
\hline 2010 & 6 & 17.8 & 23.3 & $20.8-25.8$ & $19.8-26.8$ \\
\hline 2010 & 7 & 20.0 & 24.0 & $21.5-26.5$ & $20.5-27.5$ \\
\hline 2010 & 8 & 17.1 & 23.1 & $20.6-25.6$ & $19.6-26.6$ \\
\hline 2010 & 9 & 15.0 & 22.4 & $19.9-24.9$ & $18.9-25.9$ \\
\hline
\end{tabular}

Table 6

External climate data in London Heathrow provided by the Met Office [90].

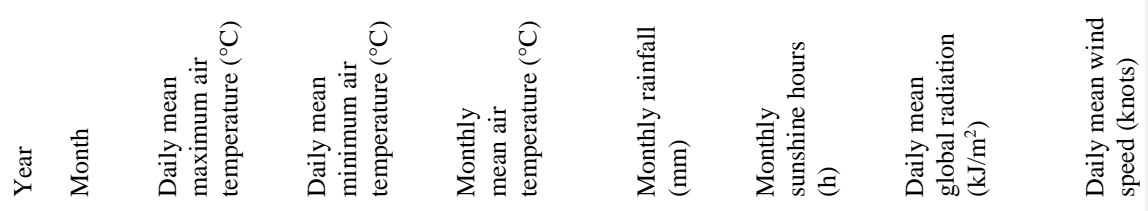




\begin{tabular}{lllllllll}
2009 & 6 & 22.4 & 12.2 & 17.3 & 34.0 & 192.8 & $20,263.4$ & 6.8 \\
2009 & 7 & 23.0 & 13.7 & 18.4 & 71.4 & 155.8 & $17,829.4$ & 9.8 \\
2009 & 8 & 23.9 & 14.1 & 19.0 & 39.6 & 167.6 & $15,452.0$ & 8.2 \\
2009 & 9 & 20.5 & 12.0 & 16.3 & 36.0 & 137.3 & $11,546.6$ & 7.7 \\
2010 & 6 & 23.5 & 12.1 & 17.8 & 12.4 & 220.1 & $20,978.2$ & 6.6 \\
2010 & 7 & 25.0 & 15.1 & 20.1 & 18.0 & 161.8 & $18,704.8$ & 8.4 \\
2010 & 8 & 21.6 & 13.2 & 17.4 & 88.6 & 110.9 & $13,283.7$ & 7.8 \\
2010 & 9 & 19.4 & 11.2 & 15.3 & 38.2 & 128.7 & $10,893.8$ & 7.8 \\
\hline
\end{tabular}

2

Notably, climate change and increasing urbanisation are likely to affect thermal comfort expectations and the population's susceptibility to the adverse health effects of heat and cold in the this paper.

9 2.2.4 Analysis during the 2010 hot spells

10

The thermal behaviour of the monitored dwellings was analysed in more detail during two hot spells that occurred in 2010. The first hot spell occurred from $22^{\text {nd }}$ June to $3^{\text {rd }}$ July 2010 . During this period, the daily running mean temperatures in the daytime exceeded $20{ }^{\circ} \mathrm{C}$ for 12 days in a row. Following this, the UK Met office declared a heatwave, set at Level $2 / 4$, for the period from $9^{\text {th }}$ to $16^{\text {th }}$ July 2010 for South East England and East Anglia. This was after temperatures reached $31{ }^{\circ} \mathrm{C}$ in London and night time temperatures levelled around $21^{\circ} \mathrm{C}$. The peak temperatures during the first hot spell were not as high as those during the second hot spell. Nonetheless, comparing a long period with consistently warm temperatures with a short period of unusually hot temperatures provides useful insights into the resilience of London building dwellings to hot spells.

20

2.2.5 Comparison with other monitoring studies

The results of the present study were compared against those of two other studies where similar monitoring data during summer periods were collected: (a) Hourly Dry Bulb Temperature data 
monitored between 1989 and 1991 in the living room and bedroom of 27 low energy houses in the

2 Milton Keynes Energy Park (MKEP), as part of a larger energy use study of 160 houses by the

3 National Energy Foundation (NEF) [58], and (b) Hourly Dry Bulb Temperature data monitored

4 between 2006 and 2007 in the living room and bedroom of 96 dwellings across the UK, the majority

5 of which with a micro Combined Heat and Power (micro-CHP) system, as part of the Carbon Trust's

6 Micro-CHP Accelerator study [92].

7

$8 \quad 3$. Results and discussion

9

103.1 Indoor overheating assessment based on fixed thresholds

11

For the purpose of this analysis, it was assumed that the high temperatures monitored during the summer period were not exceeded in the participating dwellings outside the monitoring period. This takes into account the low ambient temperatures experienced in the UK during the non-summer period. It is still possible, nevertheless, that overheating might have occurred on a few particularly warm and sunny days outside the summer season. This is likely to have resulted in a slight underestimation of the total annual hours of overheating.

Figure 4 illustrates the frequency of exceedance of fixed overheating thresholds in living rooms during occupied hours $(8 \mathrm{am}$ to $8 \mathrm{pm})$ in $2009(\mathrm{n}=94)$. It should be noted that dwellings from both years are ranked from low to high exceedance levels in order to simplify presentation. As a result, adjacent bars may not represent the same property. Living rooms in six dwellings (6\% of the sample) experienced temperatures above $28{ }^{\circ} \mathrm{C}$ for more than $1 \%$ of occupied hours and, thus, failed the CIBSE static overheating criterion. Living rooms in 13 dwellings (14\% of the sample) experienced temperatures above $25{ }^{\circ} \mathrm{C}$ for more than $5 \%$ of occupied hours and/or temperatures above $28{ }^{\circ} \mathrm{C}$ for more than $1 \%$ of occupied hours.

Figure 5 shows a similar distribution for year $2010(\mathrm{n}=91)$, with living rooms in 14 dwellings ( $15 \%$ of the sample) failing the CIBSE static overheating criterion and 25 living rooms (28\% of the sample) above the overheating criterion that considers both warm and hot thresholds. 
$28 \mathrm{am}$ ), shown in Figures 6 and 7. The hottest dwelling in the sample was a top floor, one bed, 3 internally insulated flat located in central London. The levels of threshold exceedance are summarised 4 in Table 7. Different levels of indoor overheating are observed between 2009 and 2010. According to 5 the Met Office data in Table 6 however, the summers of 2009 and 2010 were characterised by broadly similar mean monthly temperatures, sunshine hours and global radiation values. This potentially highlights the uncertainty associated with predicting overheating in dwellings only based on outdoor weather conditions

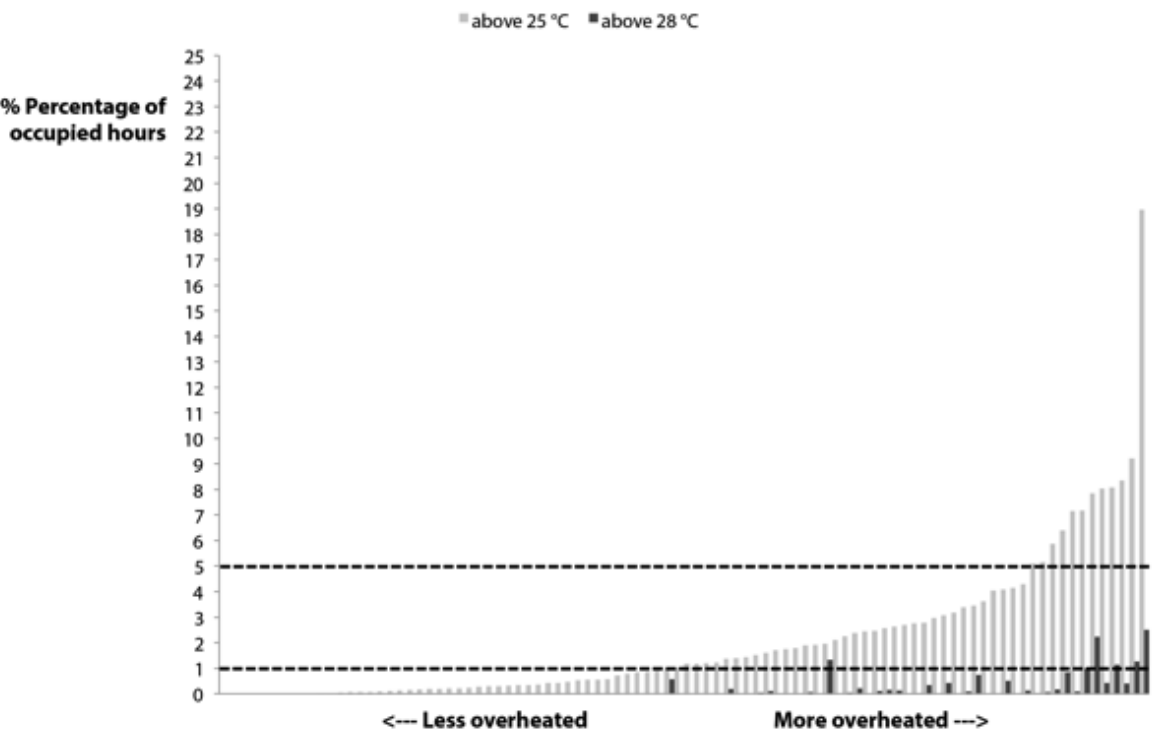

Fig. 4. Percentage of occupied hours with 2009 monitored living room Dry Bulb Temperatures exceeding the CIBSE Guide A $7^{\text {th }}$ edition [71] fixed thresholds (dashed lines) for overheating 


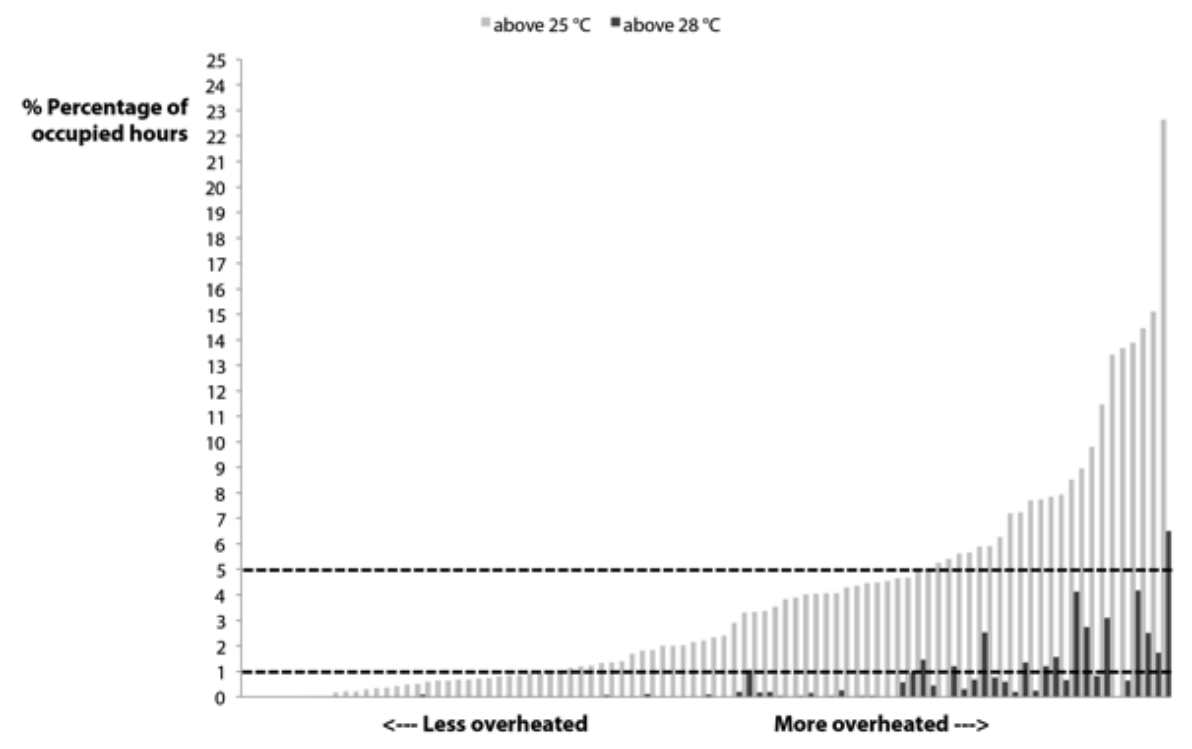

Fig. 5. Percentage of occupied hours with 2010 monitored living room Dry Bulb Temperatures exceeding the CIBSE $7^{\text {th }}$ edition [71] fixed thresholds (dashed lines) for overheating

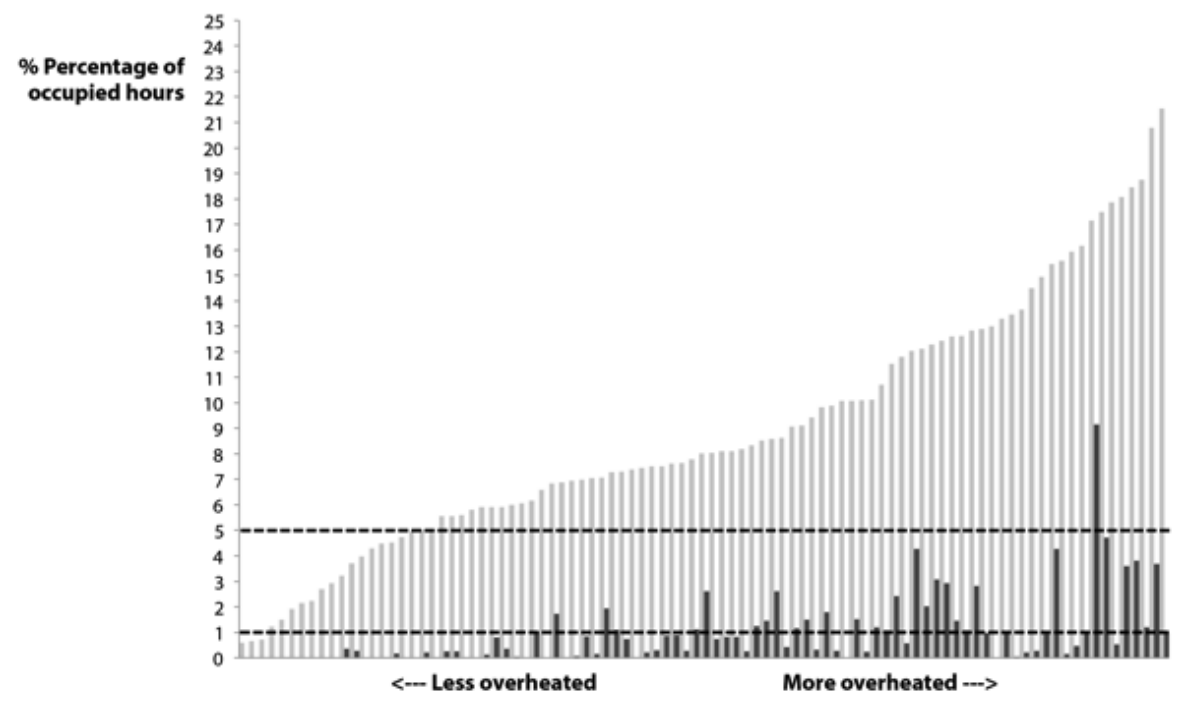

Fig. 6. Percentage of occupied hours with 2009 monitored bedroom Dry Bulb Temperatures exceeding the CIBSE $7^{\text {th }}$ edition [71] fixed thresholds (dashed lines) for overheating 


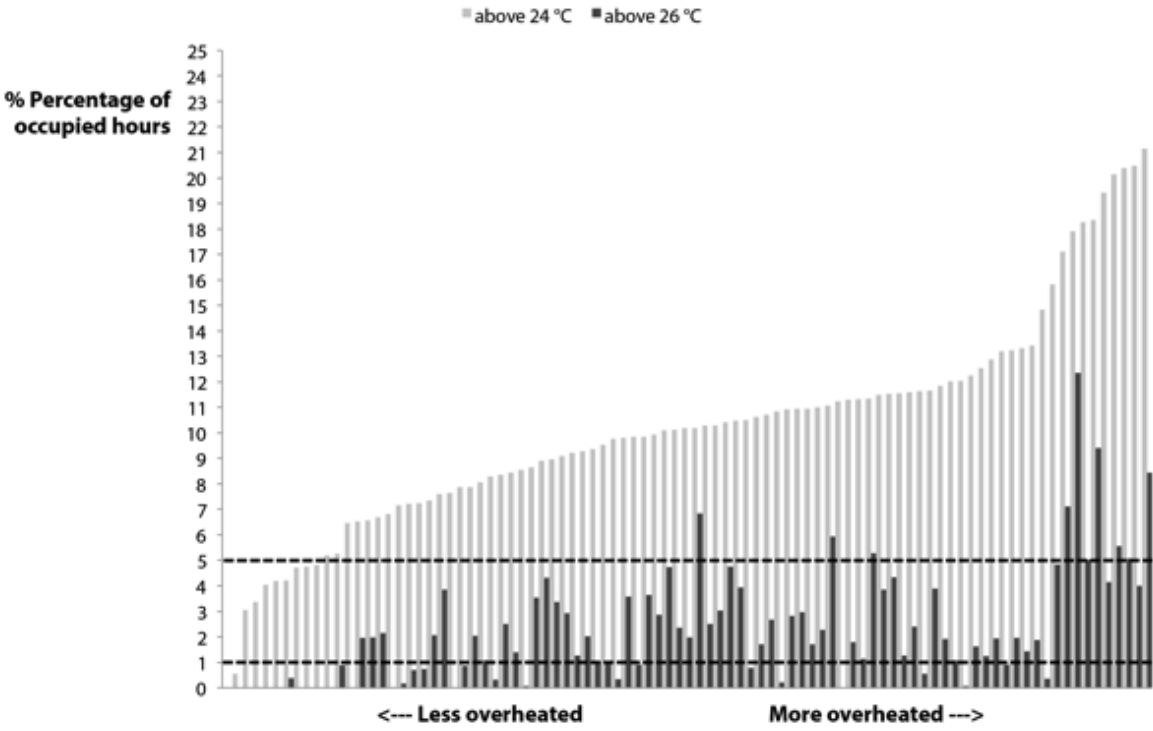

Fig. 7. Percentage of occupied hours with 2010 monitored bedroom Dry Bulb Temperatures exceeding the CIBSE $7^{\text {th }}$ edition [71] fixed thresholds (dashed lines) for overheating

Table 7.

Percentage of occupied hours with 2009 and 2010 monitored living room and bedroom Dry Bulb Temperatures exceeding the CIBSE $7^{\text {th }}$ edition [71] fixed thresholds for overheating

\begin{tabular}{|c|c|c|c|}
\hline & \multicolumn{3}{|c|}{ Number (\% percentage) of dwellings } \\
\hline Living room & $\begin{array}{l}>1 \% \mathrm{OH} \text { with } \mathrm{DBT}>28 \\
\square \mathrm{C}\end{array}$ & $\begin{array}{l}>5 \% \mathrm{OH} \text { with } \mathrm{DBT}>25 \\
\square \mathrm{C}\end{array}$ & $\begin{array}{l}>1 \% \text { OH with DBT }>28 \\
\square \mathrm{C} \text { and/or }>5 \% \text { OH with } \\
\text { DBT }>25 \square \mathrm{C}\end{array}$ \\
\hline $2009(n=94)$ & $6(6 \%)$ & $12(13 \%)$ & $13(14 \%)$ \\
\hline $2010(n=91)$ & $14(15 \%)$ & $23(25 \%)$ & $25(28 \%)$ \\
\hline Bedroom & $\begin{array}{l}>1 \% \text { OH with } \mathrm{DBT}>26 \\
\square \mathrm{C}\end{array}$ & $\begin{array}{l}>5 \% \mathrm{OH} \text { with } \mathrm{DBT}>24 \\
\square \mathrm{C}\end{array}$ & $\begin{array}{l}>1 \% \mathrm{OH} \text { with } \mathrm{DBT}>26 \\
\square \mathrm{C} \text { and } / \text { or }>5 \% \mathrm{OH} \text { with } \\
\mathrm{DBT}>24 \square \mathrm{C}\end{array}$ \\
\hline $2009(n=93)$ & $31(33 \%)$ & $75(81 \%)$ & $75(81 \%)$ \\
\hline $2010(\mathrm{n}=91)$ & $61(67 \%)$ & $81(89 \%)$ & $81(89 \%)$ \\
\hline
\end{tabular}

As part of the building survey component of this study, extensive information on building construction characteristics and occupant behaviour was gathered on the monitored dwellings. Two significant dwelling attributes, construction age and form/type were analysed in more detail. 
2 and thermal discomfort temperature thresholds, respectively, grouped according to construction age.

3 Dwellings built after 1996 tended to have indoor temperatures above thresholds for considerably

4 longer periods of time compared to dwellings built in the $19^{\text {th }}$ century or those built around the turn of

5 the century. Living rooms in post-1996 dwellings experienced temperatures above $25{ }^{\circ} \mathrm{C}$ for $6 \%$ additional summertime occupied hours on average compared to those in pre-1996 dwellings, and a similar difference was observed for bedroom temperatures above $24{ }^{\circ} \mathrm{C}$; two-tailed unpaired homoscedastic t-tests indicated that these differences between the pre-1996 and post-1996 dwellings are statistically significant at the $5 \%$ level. This finding is in general agreement with previous studies in this field that have found that recently built dwellings tend to overheat more $[25,27,61,66]$.

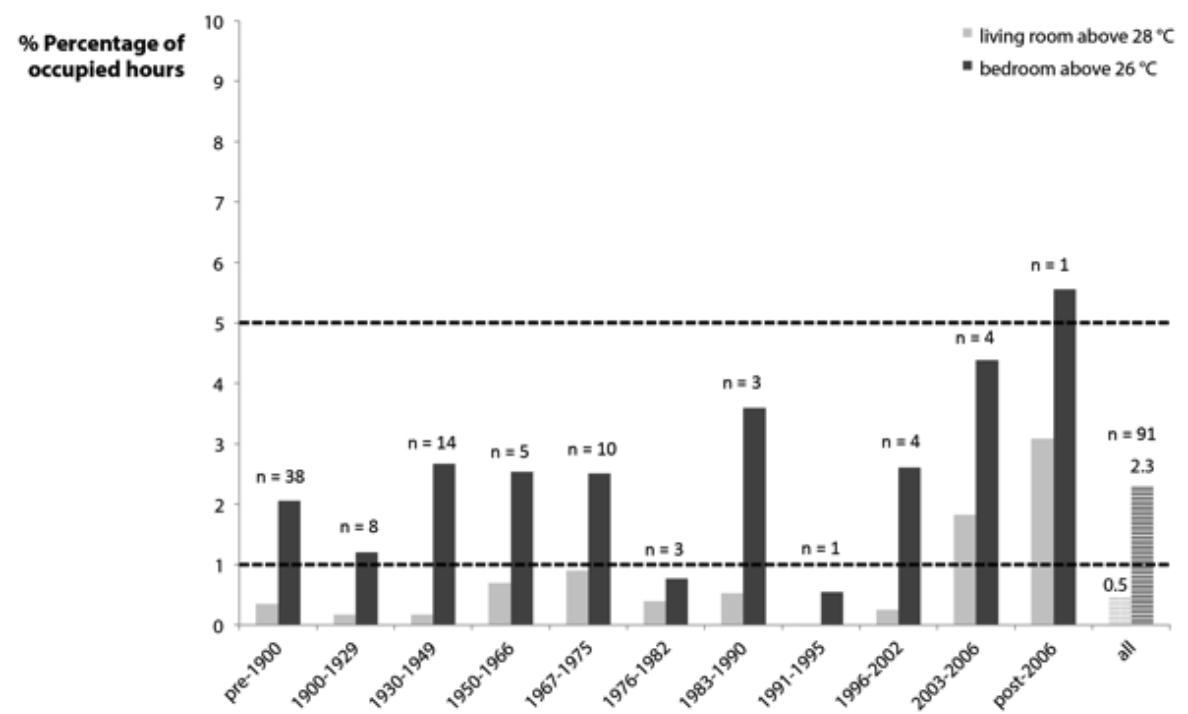

Fig. 8. Percentage of occupied hours with 2010 monitored living room and bedroom Dry Bulb Temperatures exceeding the CIBSE $7^{\text {th }}$ edition [71] fixed thresholds (dashed lines) for overheating by dwelling construction age 


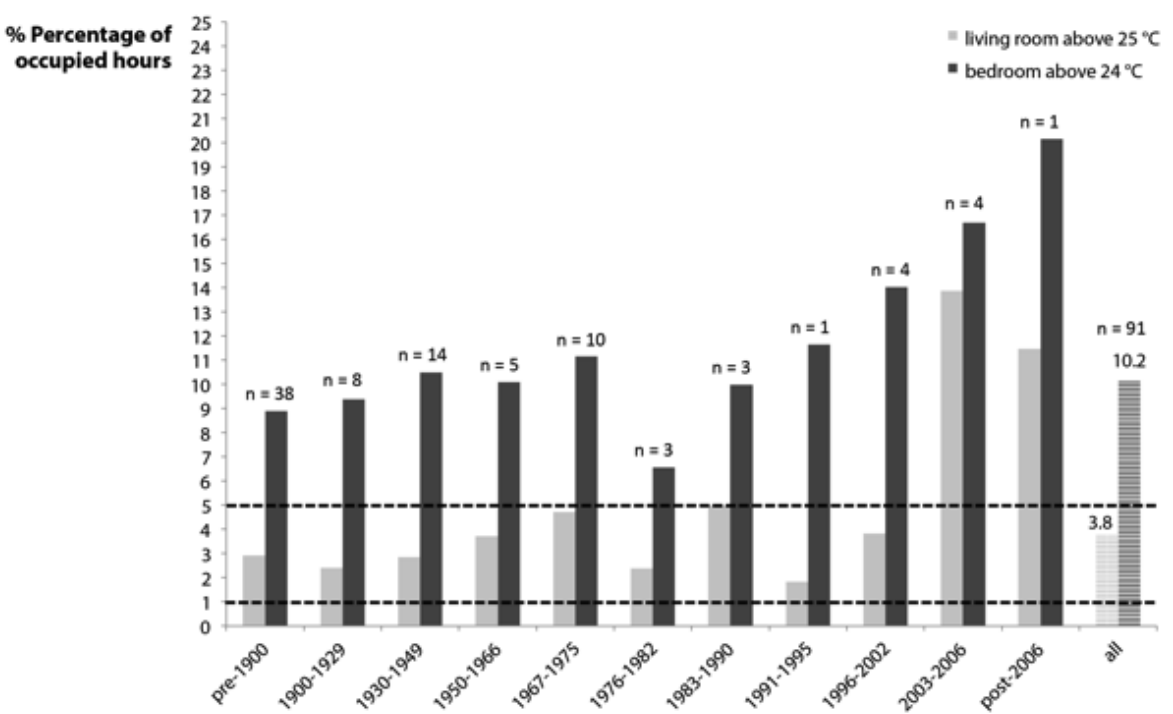

Fig. 9. Percentage of occupied hours with 2010 monitored living room and bedroom Dry Bulb Temperatures exceeding the CIBSE $7^{\text {th }}$ edition [71] fixed thresholds (dashed lines) for summer thermal discomfort by dwelling construction age

The distribution of overheating risk by dwelling type is shown in Figures 10 and 11. There is no 6 clear trend in the extent of overheating by building form. Flats and semi-detached houses tend to be above both thresholds for longer than the average duration for the whole sample. Living rooms in terraced houses and detached houses perform better than other types and better than the average of the whole sample. 


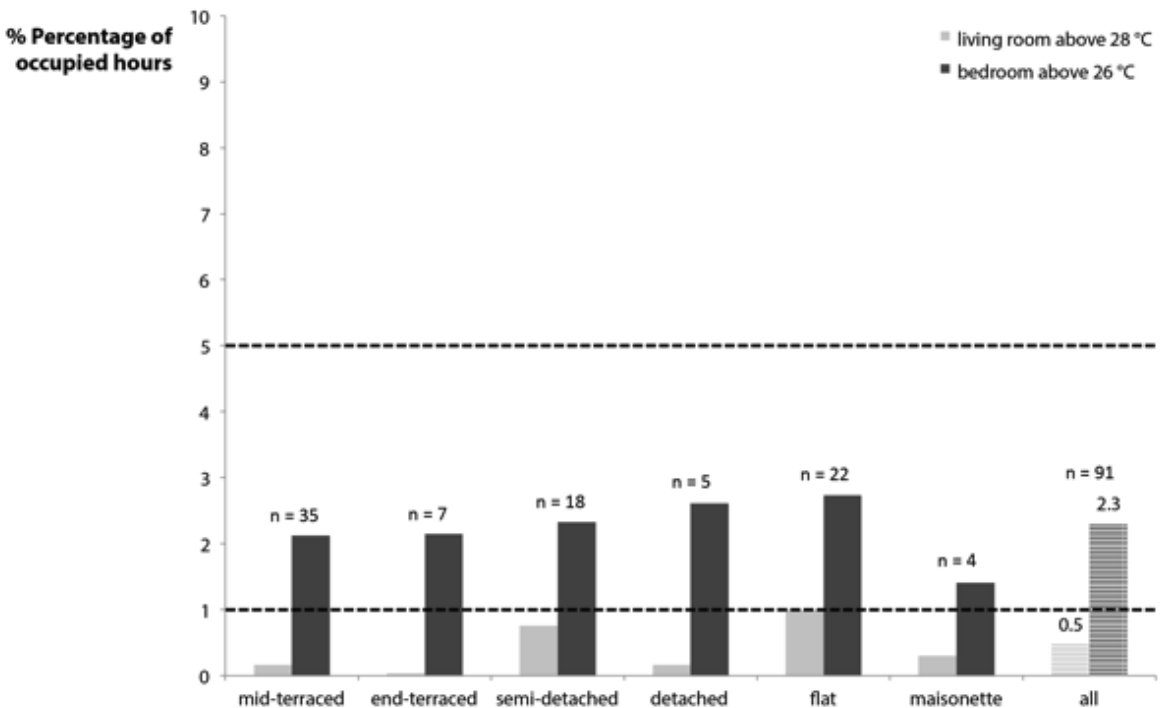

Fig. 10. Percentage of occupied hours with 2010 monitored living room and bedroom Dry Bulb Temperatures exceeding the CIBSE $7^{\text {th }}$ edition [71] fixed thresholds (dashed lines) for overheating by dwelling type

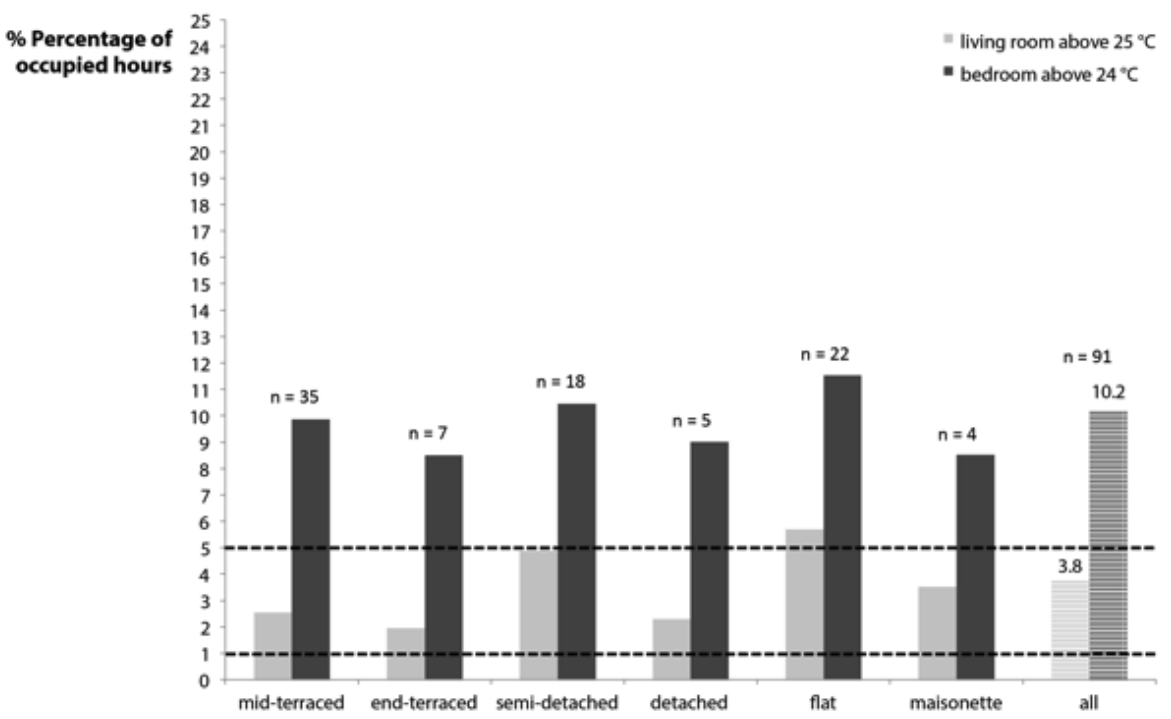

Fig. 11. Percentage of occupied hours with 2010 monitored living room and bedroom Dry Bulb Temperatures exceeding the CIBSE $7^{\text {th }}$ edition [71] fixed thresholds (dashed lines) for summer thermal discomfort by dwelling type 
Figure 12 demonstrates the distribution of occupied hours in the monitored living rooms above the 90\% acceptability adaptive thermal comfort range in 2009 and 2010. In 2009, the living room temperature in 27 dwellings ( $29 \%$ of the sample) was above the range for more than $1 \%$ of occupied hours. The corresponding figure for 2010 was 34 dwellings (37\% of the sample).

Figure 13 shows a similar distribution for bedrooms at night. In 2009, 28 dwellings (31\% of the sample) had bedrooms with more than $1 \%$ of summertime occupied hours above the thermal comfort range. Half of the bedrooms in 2010 exceeded the criterion (45 bedrooms). The extent of overheating is significantly higher in 2010 than it is in 2009. However, the difference between the two years is 11 smaller when using the adaptive criteria in comparison to the figures obtained for the fixed thresholds, which showed an approximately two-fold increase in the number of overheated properties from 2009 to 2010 (Table 7).

This once again raises the issue whereby considerably different overheating levels are observed during two years with similar external weather conditions. Whilst this may be partly attributed to the fact that the monitored sample was not identical in both years, when the identical sample was analysed the difference between years was still present. For example, out of the 63 properties that were monitored in both 2009 and 2010, the living rooms of 5 dwellings were found to exceed $28{ }^{\circ} \mathrm{C}$

19 for more than $1 \%$ of occupied hours in 2009 compared to 11 dwellings in 2010 . It may also be an 20 indication that simplified overheating criteria based on external temperature alone may be limited. 


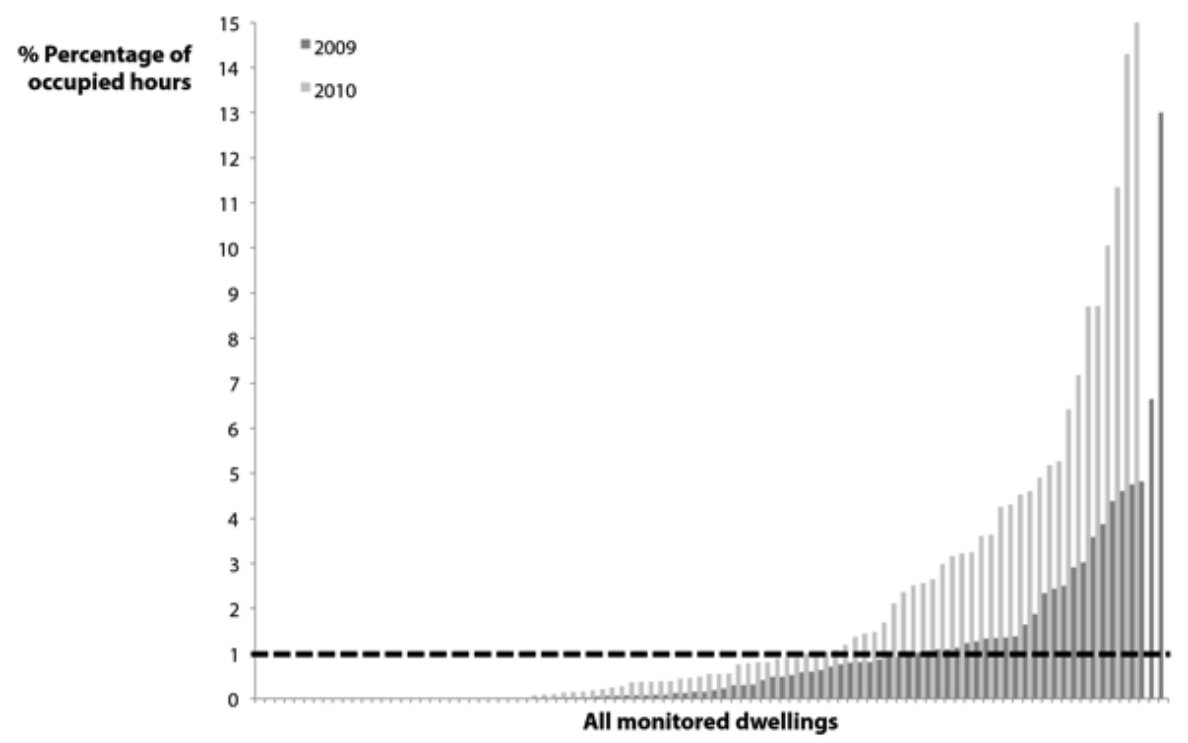

Fig. 12. Percentage of occupied hours with 2009 and 2010 monitored living room Dry Bulb Temperature exceeding the ASHRAE Standard 55 [73] adaptive comfort range (90\% acceptability)

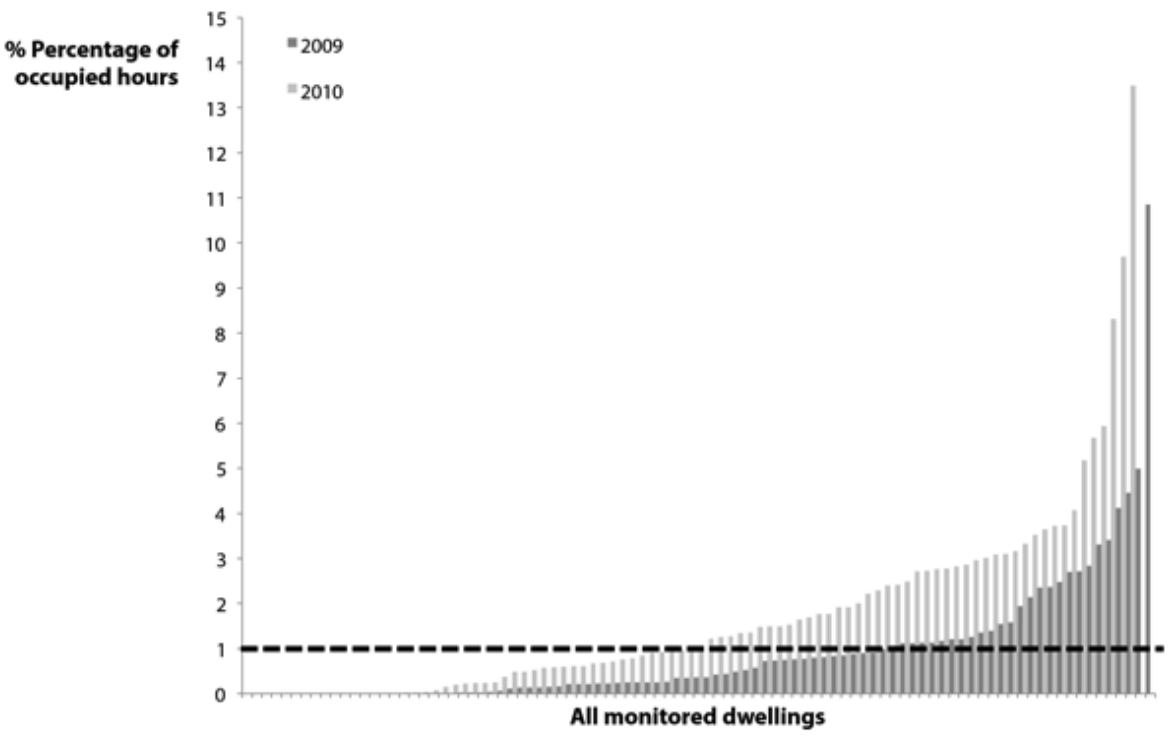

Fig. 13. Percentage of occupied hours with 2009 and 2010 monitored bedroom Dry Bulb Temperature exceeding the ASHRAE Standard 55 [73] adaptive comfort range (90\% acceptability) 3.3 Analysis during the 2010 hot spells 
The external weather conditions during the two hot spells that were observed in 2010 (from $22^{\text {nd }}$

3 June to $3^{\text {rd }}$ July 2010 and from $9^{\text {th }}$ to $16^{\text {th }}$ July 2010), as recorded by the loggers placed outside the 4 monitored dwellings were analysed. Small variations in recorded temperatures between all external 5 loggers were observed, reaching up to $4-5{ }^{\circ} \mathrm{C}$ difference between night time temperatures. This is in 6 agreement with previous measurements across London's UHI [93]. It also demonstrates the importance of using more appropriate microclimatic conditions around the dwelling to calculate the adaptive thermal comfort range as opposed to using data from weather stations that are usually located in the outskirts of cities. In this study, a combination of mean external logger temperature data and Heathrow data were used to calculate the indoor optimum comfort operative temperature range for the purposes of this study as outlined in section 2.2.3. Future work will use the external logger data to generate more localised thermal comfort ranges across the monitored sample.

In Figure 14 below, the mean indoor temperature of the whole sample is plotted against the corresponding mean outdoor temperature intervals during the two 2010 hot spells. Indoor temperature rose steadily as a response to outdoor temperature during the first hot spell. A steeper increase for outdoor temperatures between $18{ }^{\circ} \mathrm{C}$ and $20^{\circ} \mathrm{C}$ followed by a plateau at around $25^{\circ} \mathrm{C}$ and $26{ }^{\circ} \mathrm{C}$ was observed during the second hot spell. This might reflect adaptive occupant behaviour, such as window opening, taking place during warm spells that occur later in the summer. It may also suggest that dwellings may be more likely to overheat during short periods of hot weather than during longer periods of warm but less intense weather. Further analysis is needed to understand whether this difference is due to the adaptability of occupants or other factors associated with building characteristics. This analysis once again shows that, on average, living rooms maintain lower temperatures than bedrooms, irrespective of external conditions.

The impact of dwelling room and type on the indoor-outdoor relationship was subsequently investigated. Flats were overall warmer than other dwelling types and tended to have only marginally cooler bedrooms as the outdoor temperature increased, thus presenting an almost uniform temperature profile throughout. No clear trend was observed in semi-detached houses, which were cooler than 
1 flats and had living rooms only slightly cooler than bedrooms during the night. The lowest

2 temperatures were observed in detached and terraced houses where living rooms remained around 2-

$3 \quad 2.5^{\circ} \mathrm{C}$ cooler than bedrooms during the night time.

4

5

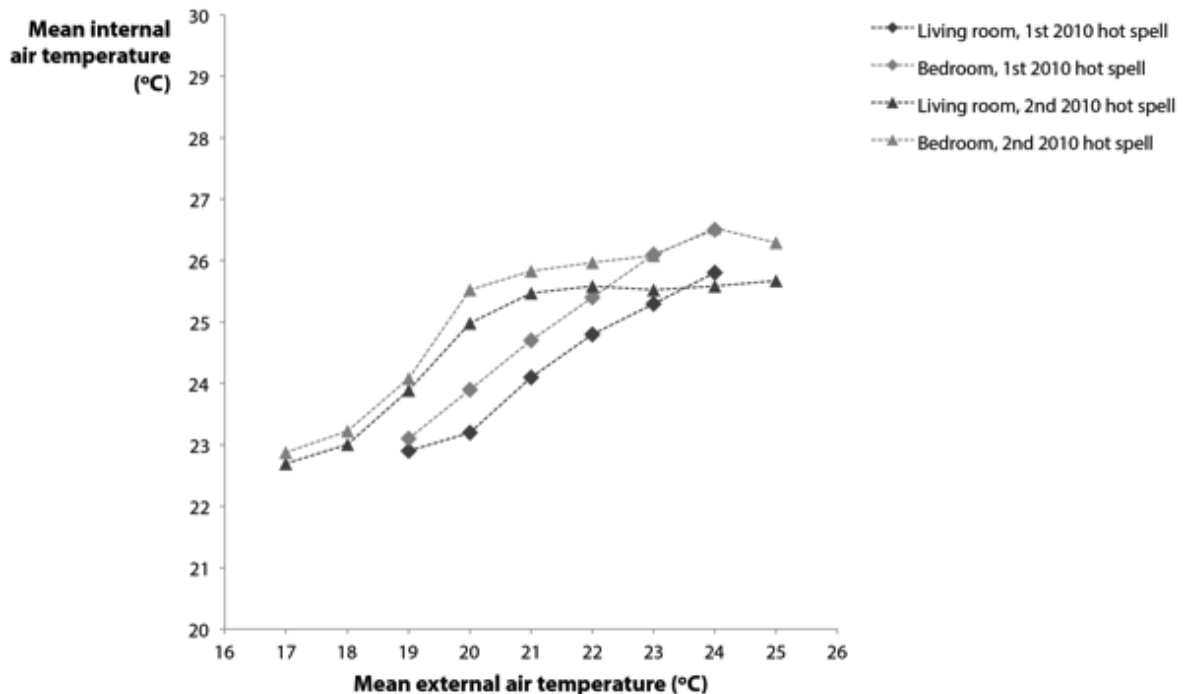

Fig. 14. Mean internal vs. external air temperature in the monitored living rooms and bedrooms during the $1^{\text {st }}$ ( $22^{\text {nd }}$ June to $3^{\text {rd }}$ July) and $2^{\text {nd }}\left(9^{\text {th }}\right.$ to $16^{\text {th }}$ July) 2010 hot spell

\subsection{Comparison with other monitoring studies}

Figure 15 illustrates the distribution of internal temperatures in the monitored dwellings in comparison to the MKEP and Micro-CHP Accelerator studies. The inter-quartile range of daily mean internal temperatures in the living rooms and bedrooms across all three studies for various daily mean external temperatures is shown. Dwellings in the MKEP study consistently show higher internal temperatures than the other two studies. This may be attributed to lower heat losses from the building fabric since these low-energy houses were built to higher standards than required by the Building 
1 Regulations at that time, however they were designed before overheating calculations were 2 mandatory.

3 The temperature profiles of the London dwellings monitored in the present study are quite similar 4 to those obtained from the micro-CHP study. Dwellings in the micro-CHP study were drawn from a 5 non-random, volunteer sample with micro-CHP systems installed in their homes. As a result, this 6 comparison does not indicate that the present sample of London dwellings is necessarily representative. It nevertheless shows that the findings of this study are in broad agreement with those of existing studies.

The agreement between the three studies appears to widen as the daily mean external air temperature rises. A potential explanation for this is that varying natural ventilation behaviours occur 11 above certain external temperature thresholds, thus resulting in a wider variation in internal temperatures across the three studies.

13

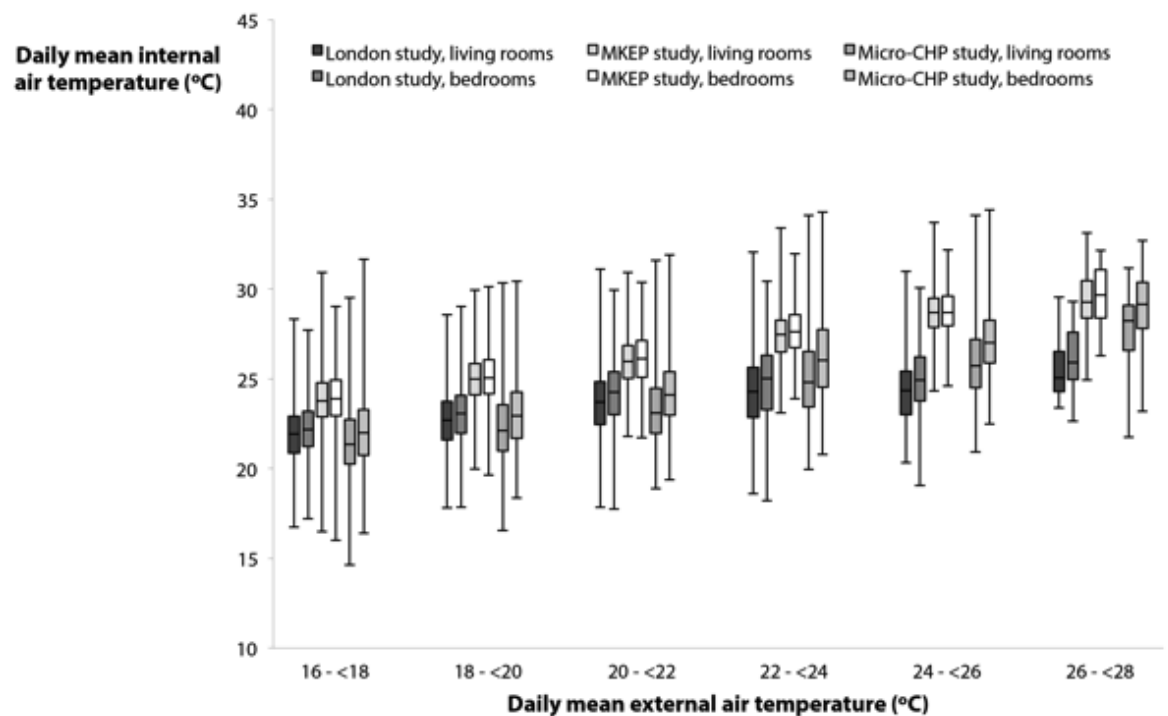

Fig. 15. Internal vs. external air temperature profile in the 123 monitored dwellings in relation to other studies (the boxplots indicate the minimum, first quartile, median, third quartile, and maximum values) 


\section{Conclusions}

This paper set out to present the results of a study of the summer thermal performance of 122 London dwellings that were monitored during the summers of 2009 and 2010. Analysis of the monitoring data shows that the problem of overheating in London homes is widespread and not limited to flats or newly built properties as usually predicted by studies relying on dynamic thermal simulation. Dwellings built since 1996, which were potentially constructed to higher energy efficiency standards, tended to have significantly higher indoor temperatures above thresholds for longer than older properties. However, the fact that bedrooms in three out of four properties within the whole sample failed the fixed thresholds criteria means that targeting particular categories of dwellings may not adequately address the issue of summertime overheating.

In spite of the limitations of the sample, the findings suggest that a substantial proportion or even the majority of London residents regularly experience bedroom temperatures that could potentially compromise their quality of sleep and hence their productivity the next day. Further research on overheating in sleeping spaces is required to quantify its impact on human performance and wellbeing. Living rooms in houses were overall cooler than bedrooms, however, this may simply be a result of a large number of monitored dwellings not having been heavily occupied during the daytime. Considerable differences in the levels of indoor overheating across the monitored samples were observed between 2009 and 2010 despite broadly similar external weather conditions during the two summers. This highlights the need to go beyond simplified models of external conditions, and factor in the UHI and local microclimate characteristics as part of assessment studies. 

recommended in the future, which entails regular monitoring of indoor thermal conditions of large, heterogeneous dwelling samples, combined with a comprehensive study of adaptive cooling behaviour and attitudes towards active cooling systems. This will create a robust evidence base to inform Building Regulations and other policy initiatives related to the climate resilience of the UK housing sector.

5. Acknowledgements

The LUCID project was funded by an Engineering and Physical Sciences Research Council (EPSRC) grant (EP/E016375/1). T. Oreszczyn, A. Summerfield and M.Davies are currently supported via the RCUK Centre for Energy Epidemiology grant (EP/K011839/1). The authors would like to thank the study participants for their time and input.

6. References

16

1. IPCC. Climate Change 2014, Synthesis Report, Summary for Policymakers [Internet]. Geneva, Switzerland; 2014. Available from: http://www.ipcc.ch/pdf/assessmentreport/ar5/syr/AR5_SYR_FINAL_SPM.pdf

2. Perkins SE, Alexander L V., Nairn JR. Increasing frequency, intensity and duration of observed global heatwaves and warm spells. Geophys Res Lett. 2012;39(20):1-5.

3. Kala J, De Kauwe MG, Pitman AJ, Medlyn BE, Wang Y-P, Lorenz R, et al. Impact of the representation of stomatal conductance on model projections of heatwave intensity. Nat Sci Reports [Internet]. 2016;6(23418). Available from: http://www.nature.com/articles/srep23418

4. Murphy JM, Sexton DMH, Jenkins GJ, Boorman PM, Booth BBB, Brown CC, et al. UK Climate Projections Science Report: Climate change projections. Exeter, UK; 2009.

5. Hall JW, Dawson RJ, Walsh CL, Barker T, Barr SL, Batty M, et al. Engineering Cities, How can cities grow whilst reducing emissions and vulnerability? [Internet]. Newcastle, UK; 2009. Available from: http://www.ncl.ac.uk/ceser/researchprogramme/reports/Tyndall.pdf.pdf

6. Kovats S, Hajat S. Heat stress and public health: A critical review. Annu Rev Public Health. 2008;29:41-55.

7. Fouillet A, Rey G, Laurent F, Pavillon G, Bellec S, Guihenneuc-Jouyaux C, et al. Excess mortality related to the August 2003 heat wave in France. Int Arch Occup Environ Health. 
2006;80(1):16-24.

8. Fouillet A, Rey G, Wagner V, Laaidi K, Empereur-Bissonnet P, Le Tertre A, et al. Has the impact of heat waves on mortality changed in France since the European heat wave of summer 2003? A study of the 2006 heat wave. Int J Epidemiol. 2008;37(2):309-17.

9. Kosatsky T. The 2003 European heat waves. Eurosurveillance [Internet]. 2005;10(7):1-9. Available from: http://www.eurosurveillance.org/ViewArticle.aspx?ArticleId=551

10. Johnson H, Kovats RS, McGregor GR, Stedman JR, Gibbs M, Walton H, et al. The impact of the 2003 heatwave on mortality and hospital admissions in England. Heal Stat Q. 2005;25(7):6-11.

11. WHO. Heat-waves: Risks and responses, Health and Global Environmental Change, Series No. 2, Energy, Environment and Sustainable Development [Internet]. Copenhagen, Denmark; 2004. Available from:

http://www.euro.who.int/_data/assets/pdf_file/0008/96965/E82629.pdf?ua=1

12. Menne B, Matthies F. Improving public health responses to extreme weather/heat-waves: EuroHEAT [Internet]. WHO,. Copenhagen, Denmark; 2009. Available from: http://www.euro.who.int/_data/assets/pdf_file/0010/95914/E92474.pdf

13. PHE. Heatwave Plan for England. London, UK; 2015.

14. Oke TR. Boundary Layer Climates. 2nd editio. Abingdon, UK: Routledge; 1987.

15. Grimmond S. Urbanization and global environmental change: Local effects of urban warming. Geogr J [Internet]. 2007;173(1):83-8. Available from: http://doi.wiley.com/10.1111/j.14754959.2007.232_3.x

16. Santamouris M, Cartalis C, Synnefa A, Kolokotsa D. On the impact of urban heat island and global warming on the power demand and electricity consumption of buildings-A review. Energy Build [Internet]. 2015;98:119-24. Available from: http://linkinghub.elsevier.com/retrieve/pii/S0378778814007907

17. Hajat S, Kovats RS, Lachowycz K. Heat-related and cold-related deaths in England and Wales: Who is at risk? Occup Environ Med. 2007;64(2):93-100.

18. Milojevic A, Wilkinson P, Armstrong B, Davies M, Mavrogianni A, Bohnenstengel S, et al. Impact of London's Urban Heat Island on heat-related mortality. 2011;22(1 (Supplement)):S182-3.

19. UK Government. Climate Change Act 2008, Chapter 27 [Internet]. London, UK; 2008. Available from: http://www.legislation.gov.uk/ukpga/2008/27/pdfs/ukpga_20080027_en.pdf

20. Shrubsole C, Macmillan A, Davies M, May N. 100 Unintended consequences of policies to improve the energy efficiency of the UK housing stock. Indoor Built Environ [Internet]. 2014;23(3):340-52. Available from: http://ibe.sagepub.com/cgi/doi/10.1177/1420326X14524586

21. Dengel A, Swainson M. Overheating in new homes, A review of the evidence. Milton Keynes, $\mathrm{UK} ; 2012$.

22. Santamouris M, Kolokotsa D. Passive cooling dissipation techniques for buildings and other structures: The state of the art. Energy Build [Internet]. 2013;57:74-94. Available from: http://dx.doi.org/10.1016/j.enbuild.2012.11.002

23. Gupta R, Gregg M, Williams K. Cooling the UK housing stock post-2050s. Build Serv Eng 
Res Technol [Internet]. 2015;36(2):196-220. Available from: http://search.ebscohost.com/login.aspx?direct=true \&db=bth\&AN=101042772\&site=ehost-live

24. ZCH. Solutions to Overheating in Homes, Evidence Review [Internet]. London, UK; 2016. Available from: http://www.zerocarbonhub.org/sites/default/files/resources/reports/ZCHOverheatingEvidenceReview.pdf

25. Beizaee A, Lomas KJ, Firth SK. National survey of summertime temperatures and overheating risk in English homes. Build Environ [Internet]. 2013;65:1-17. Available from: http://dx.doi.org/10.1016/j.buildenv.2013.03.011

26. ZCH. Overheating in Homes, The big picture, Full report. London, UK; 2015.

27. Hulme J, Beaumont A, Summers C. Energy Follow-Up Survey 2011, Report 7: Thermal comfort \& overheating. Watford, UK; 2013.

28. Hulme J, Beaumont A, Summers C. Energy Follow-Up Survey 2011, Report 9: Domestic appliances, cooking \& cooling equipment. Watford, UK; 2013.

29. Cooper G. Air-conditioning America: Engineers and the Controlled Environment, 1900-1960. 2nd editio. Baltimore, MD, USA: Johns Hopkins University Press; 2002.

30. Frontier Economics Ltd, Irbaris LLP, Ecofys. Economics of Climate Resilience Buildings and Infrastructure Theme, Overheating in Residential Housing, Annexes CA0401 [Internet]. London, UK; 2013. Available from:

http://randd.defra.gov.uk/Default.aspx?Module=More $\&$ Location=None $\&$ ProjectID=18016

31. Collins L, Natarajan S, Levermore G. Climate change and future energy consumption in UK housing stock. Build Serv Eng Res Technol [Internet]. 2010;31(1):75-90. Available from: http://dx.doi.org/10.1177/0143624409354972

32. Wu A, Pett J. Cold Comfort for Kyoto? Carbon Implications from Increasing Residential Cooling Demand, A Scoping Report [Internet]. London, UK; 2006. Available from: http://www.ukace.org/wp-content/uploads/2012/11/ACE-Research-2006-08-Cold-Comfortfor-Kyoto-full-report.pdf

33. Day AR, Jones PG, Maidment GG. Forecasting future cooling demand in London. Energy Build [Internet]. 2009;41(9):942-8. Available from: http://linkinghub.elsevier.com/retrieve/pii/S0378778809000838

34. BRE. SAP 2005, The Government's Standard Assessment Procedure for Energy Rating of Dwellings, 2005 edition, revision 3 [Internet]. Watford, UK; 2009. Available from: http://www.bre.co.uk/filelibrary/SAP/2009/SAP-2009_9-90.pdf

35. Tillson A-A, Oreszczyn T, Palmer J. Assessing impacts of summertime overheating: some adaptation strategies. Build Res Inf [Internet]. 2013;41(March 2015):652-61. Available from: http://www.tandfonline.com/doi/abs/10.1080/09613218.2013.808864

36. Anderson M, Carmichael C, Murray V, Dengel A, Swainson M. Defining indoor heat thresholds for health in the UK. Perspect Public Health [Internet]. 2013;133(3):158-64. Available from: http://www.ncbi.nlm.nih.gov/pubmed/22833542

37. CCC ASC. Managing climate risks to well-being and the economy, Progress Report 2014 [Internet]. London, UK; 2014. Available from:

http://www.theccc.org.uk/publication/managing-climate-risks-to-well-being-and-the-economyasc-progress-report-2014/

38. DCLG. Investigation into overheating in homes, Literature review. London, UK: Department 
for Communities and Local Government (DCLG); 2012.

39. DCLG. Investigation into overheating in homes, Analysis of gaps and recommendations. London, UK: Department for Communities and Local Government (DCLG); 2012.

40. CIBSE. TM52, The limits of thermal comfort: Avoiding overheating in European buildings. London, UK; 2013.

41. DEFRA. The National Adaptation Programme: Making the Country Resilient to a Changing Climate [Internet]. London, UK; 2013. Available from: https://www.gov.uk/government/uploads/system/uploads/attachment_data/file/209866/pb1394 2-nap-20130701.pdf

42. NHBC Foundation. Understanding overheating - where to start: An introduction for house builders and designers. Milton Keynes, UK; 2012.

43. de Wilde P, Coley D. The implications of a changing climate for buildings. Build Environ. 2012;55:1-7.

44. Gul MS, Jenkins D, Patidar S, Menzies G, Banfill P, Gibson G. Communicating future overheating risks to building design practitioners: Using the Low Carbon Futures tool. Build Res Inf [Internet]. 2015;36(2):182-95. Available from:

http://search.ebscohost.com/login.aspx ?direct=true \&db=bth\&AN=101042779\&site=ehost-live

45. Holmes MJ, Hacker JN. Climate change, thermal comfort and energy: Meeting the design challenges of the 21st century. Energy Build. 2007;39(7):802-14.

46. Mavrogianni A, Wilkinson P, Davies M, Biddulph P, Oikonomou E. Building characteristics as determinants of propensity to high indoor summer temperatures in London dwellings. Build Environ [Internet]. 2012;55:117-30. Available from: http://dx.doi.org/10.1016/j.buildenv.2011.12.003

47. McLeod RS, Hopfe CJ, Kwan A. An investigation into future performance and overheating risks in Passivhaus dwellings. Build Environ [Internet]. 2013;70:189-209. Available from: http://dx.doi.org/10.1016/j.buildenv.2013.08.024

48. Oikonomou E, Davies M, Mavrogianni A, Biddulph P, Wilkinson P, Kolokotroni M. Modelling the relative importance of the urban heat island and the thermal quality of dwellings for overheating in London. Build Environ [Internet]. 2012;57:223-38. Available from: http://dx.doi.org/10.1016/j.buildenv.2012.04.002

49. Porritt S, Shao L, Cropper P, Goodier C. Adapting dwellings for heat waves. Sustain Cities Soc [Internet]. Elsevier B.V.; 2011;1(2):81-90. Available from: http://dx.doi.org/10.1016/j.scs.2011.02.004

50. Porritt SM, Cropper PC, Shao L, Goodier CI. Ranking of interventions to reduce dwelling overheating during heat waves. Energy Build [Internet]. 2012;55:16-27. Available from: http://linkinghub.elsevier.com/retrieve/pii/S0378778812000898

51. Taylor J, Davies M, Mavrogianni A, Shrubsole C, Hamilton I, Das P, et al. Mapping indoor overheating and air pollution risk modification across Great Britain: A modelling study. Build Environ [Internet]. 2016;99:1-12. Available from: http://linkinghub.elsevier.com/retrieve/pii/S0360132316300105

52. Symonds P, Taylor T, Chalabi Z, Mavrogianni A, Davies M, Hamilton I, et al. Development of an England-wide indoor overheating and air pollution model using artificial neural networks. J Build Perform Simul. 2016; In press. 
53. Taylor J, Davies M, Mavrogianni A, Chalabi Z, Biddulph P, Oikonomou E, et al. The relative importance of input weather data for indoor overheating risk assessment in London dwellings. Build Environ. 2014;76:81-91.

54. Ji Y, Fitton R, Swan W, Webster P. Assessing overheating of the UK existing dwellings - A case study of replica Victorian end terrace house. Build Environ [Internet]. 2014;77(2014):111. Available from: http://dx.doi.org/10.1016/j.buildenv.2014.03.012

55. Mavrogianni A, Davies M, Taylor J, Chalabi Z, Biddulph P, Oikonomou E, et al. The impact of occupancy patterns, occupant-controlled ventilation and shading on indoor overheating risk in domestic environments. Build Environ [Internet]. 2014;78:183-98. Available from: http://dx.doi.org/10.1016/j.buildenv.2014.04.008

56. Wright AJ, Young AN, Natarajan S. Dwelling temperature and comfort during the August 2003 heat wave. Build Serv Eng Res Technol. 2005;26(4):285-300.

57. Firth S, Benson P, Wright AJ. The 2006 heatwave: Its effect on the thermal comfort of dwellings. Third Annual Meeting, Network for Comfort and Energy Use in Buildings (NCEUB). Windsor, UK: Network for Comfort and Energy Use in Buildings (NCEUB); 2007.

58. Summerfield AJ, Lowe RJ, Bruhns HR, Caeiro JA, Steadman JP, Oreszczyn T. Milton Keynes Energy Park revisited: Changes in internal temperatures and energy usage. Energy Build. 2007;39(7):783-91.

59. Young AN, Pathan A, Oreszczyn T. Domestic air conditioning - Occupant use and operational efficiency, Final report. London, UK; 2007.

60. Pathan A, Young A, Oreszczyn T. UK Domestic Air Conditioning: A study of occupant use and energy efficiency. Proceedings of "Air Conditioning and the Low Carbon Cooling Challenge”, 5th Windsor Conference, 27th-29th July 2008. Windsor, UK; 2008. p. 27-9.

61. Firth S, Wright A. Investigating the thermal characteristics of English dwellings: Summer temperatures. Proceedings of "Air Conditioning and the Low Carbon Cooling Challenge", 5th Windsor Conference, 27th-29th July 2008. Windsor, UK: Network for Comfort and Energy Use in Buildings (NCEUB); 2008.

62. Lomas KJ, Kane T. Summertime temperatures and thermal comfort in UK homes. Build Res Inf [Internet]. 2013;41(3):259-80. Available from: http://www.scopus.com/inward/record.url?eid=2-s2.084876211342\&partnerID=40\&md5=689ba31d894e461c921725e56066eeaa

63. Oraiopoulos A, Kane T, Firth SK, Lomas KJ. Measured internal temperatures in UK Homes A time series analysis and modelling approach. Energy Procedia [Internet]. 2015;78:2844-50. Available from: http://www.sciencedirect.com/science/article/pii/S1876610215023772

64. Pana E. Summertime temperatures and overheating risk: Does orientation affect comfort in bedrooms in the UK context? Proceedings of 3rd Conference: People and Buildings, 20th September 2013. London, UK: Westminster University, School of Architecture and the Built Environment; 2013.

65. Baborska-Narozny M, Stevenson F, Chatterton P. Temperature in housing: Stratification and contextual factors. Eng Sustain. 2015;9:1-17.

66. Mavrogianni A, Taylor J, Davies M, Thoua C, Kolm-Murray J. Urban social housing resilience to excess summer heat. Build Res Inf [Internet]. 2015;43(3):316-33. Available from: http://dx.doi.org/10.1080/09613218.2015.991515

67. Morgan C, Foster J, Sharpe T, Poston A. Overheating in Scotland: Lessons From 26 
Monitored Low Energy Homes. CISBAT 2015 International Conference "Future Buildings and Districts - Sustainability from Nano to Urban Scale", 9-11 September 2015 [Internet]. Lausanne, Switzerland: Conférence Internationale Energie Solaire et Bâtiment (CISBAT); 2015. p. 167-72. Available from: http://radar.gsa.ac.uk/3719/

68. Tabatabaei Sameni SM, Gaterell M, Montazami A, Ahmed A. Overheating investigation in UK social housing flats built to the Passivhaus standard. Build Environ [Internet]. 2015;92:222-35. Available from: http://dx.doi.org/10.1016/j.buildenv.2015.03.030

69. Toledo L, Cropper PC, Wright AJ. Unintended consequences of sustainable architecture: Evaluating overheating risks in new dwellings. 32th International Conference on Passive and Low Energy Architecture (PLEA), Cities, Buildings, People: towards Regenerative Environments, 11-13 July 2016. Los Angeles, USA: Passive and Low Energy Architecture (PLEA); 2016

70. Vellei M, Ramallo-González AP, Kaleli D, Lee J, Natarajan S. Investigating the overheating risk in refurbished social housing. Proceedings of 9th Windsor Conference: Making Comfort Relevant, 7-10 April 2016. Windsor, UK: Network for Comfort and Energy Use in Buildings (NCEUB); 2016.

71. CIBSE. Environmental design, CIBSE Guide A, 7th edition, Issue 2. London, UK; 2007.

72. ZCH. Next steps in defining overheating, Discussion paper. London, UK; 2016.

73. ASHRAE. ANSI/ASHRAE Standard 55-2013, Thermal environmental conditions for human occupancy. Atlanta, USA; 2013.

74. Mavrogianni A, Pathan A, Oikonomou E, Biddulph P, Symonds P, Davies M. Inhabitant actions and summer overheating risk in London dwellings. Build Res Inf. 2017;45(1-2):11942.

75. Mavrogianni A, Davies M, Wilkinson P, Pathan A. London housing and climate change: Impact on comfort and health - Preliminary results of a summer overheating study. Open House Int. 2010;35(2):49-59.

\section{ONS. 2011 Census. London, UK; 2016.}

77. Onset Corporation. HOBO Temperature/Relative Humidity/Light/External Data Logger, Part \# U12-012. Onset Corporation [Internet]. Available from: http://www.onsetcomp.com/products/data-loggers/u12-012

78. CaRB. Carbon Reduction in Buildings (CaRB): A socio-technical, longitudinal study of carbon use in buildings [Internet]. 2016 [cited 2016 Mar 15]. Available from: http://www.ucl.ac.uk/carb/

79. Anderson BR, Chapman PF, Cutland NG, Dickson CM, Henderson G, Henderson JH, et al. BREDEM-12, Model description, 2001 update. Watford, UK; 2002.

80. Mylona A, Mavrogianni A, Davies M, Wilkinson P. Defining overheating, Evidence review. London, UK; 2015.

81. CIBSE. Environmental design, CIBSE Guide A, 8th edition. London, UK: Chartered Institution of Building Services Engineers (CIBSE); 2016.

82. Walikewitz N, Jänicke B, Langner M, Meier F, Endlicher W. The difference between the mean radiant temperature and the air temperature within indoor environments: A case study during summer conditions. Build Environ. 2015;84:151-61. 
83. CIBSE. TM36, Climate change and the indoor environment: Impacts and adaptation. London, UK; 2007.

84. Nicol FJ, Hacker J, Spires B, Davies H. Suggestion for new approach to overheating diagnostics. Build Res Inf. 2009;37(4):348-57.

85. de Dear R, Brager G, Cooper D. Developing an adaptive model of thermal comfort and preference, Final Report, ASHRAE RP-884 [Internet]. Sydney, Australia and Berkeley, USA; 1997. Available from: http://repositories.cdlib.org/cedr/cbe/ieq/deDear1998_ThermComPref

86. BSI. BS EN 15251: 2007, Indoor environmental input parameters for design and assessment of energy performance of buildings - addressing indoor air quality, thermal environment, lighting and acoustics. London, UK; 2007.

87. Humphreys MA. Quantifying occupant comfort: Are combined indices of the indoor environment practicable? Build Res Inf [Internet]. 2005;33(4):317-25. Available from: http://www.tandfonline.com/action/journalInformation?journalCode=rbri20ไnhttp://dx.doi.org/ $10.1080 / 09613210500161950$

88. McCartney KJ, Fergus NJ. Developing an adaptive control algorithm for Europe. Energy Build. 2002;34:623-35.

89. Oseland NA. Predicted and reported thermal sensation in climate chambers, offices and homes. Energy Build. 1995;23(2):105-15.

90. Met Office. Observational data [Internet]. 2016. [cited 2016 Aug 4]. Available from: http://www.metoffice.gov.uk/industry/data/commercial/observational

91. Arbuthnott K, Hajat S, Heaviside C, Vardoulakis S. Changes in population susceptibility to heat and cold over time, assessing adaptation to climate change. Environmental Health. 2016;15(Suppl 1):S33.

92. Carbon Trust. Micro-CHP Accelerator [Internet]. London, UK; 2011. Available from: https://www.carbontrust.com/media/77260/ctc788_micro-chp_accelerator.pdf

93. Watkins R, Palmer J, Kolokotroni M, Littlefair P. The London Heat Island: results from summertime monitoring. Build Serv Eng Res Technol [Internet]. 2002;23(2002):97-106. Available from: http://bse.sagepub.com/content/23/2/97.full.pdf + html 